Alma Mater Studiorum - Università di Bologna DEPARTMENT OF ECONOMICS

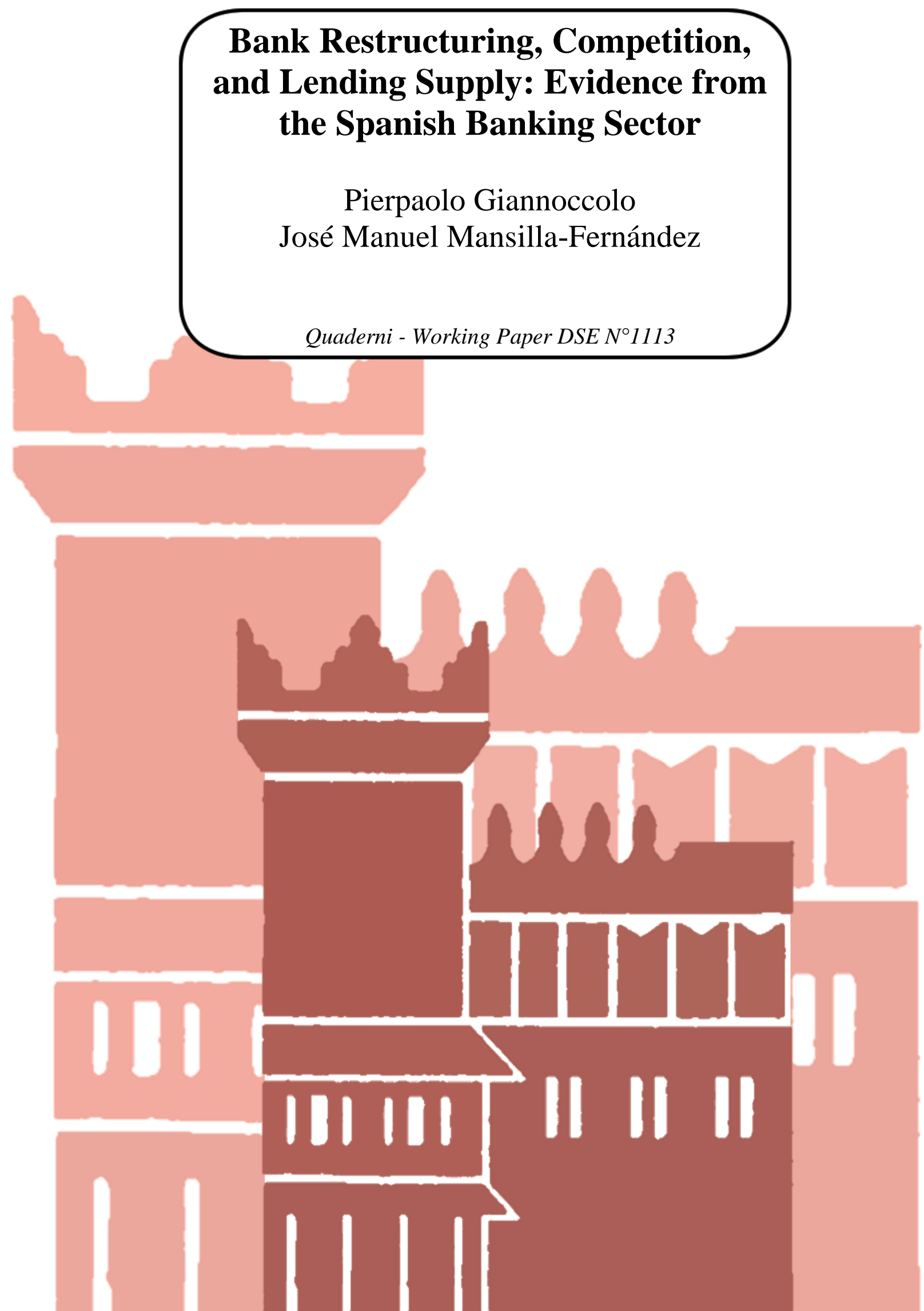




\title{
Bank Restructuring, Competition, and Lending Supply: Evidence from the Spanish Banking Sector *
}

\author{
Pierpaolo Giannoccolo ${ }^{\dagger} \quad$ José Manuel Mansilla-Fernández ${ }^{\ddagger}$ \\ This draft: \\ November 6, 2017
}

\begin{abstract}
This article analyses the effects of the bank restructuring process performed in Spain between 2010 and 2016. First, we create a unique dataset by combining information from Bankscope and the Table of Public Financial Assistance released by the Bank of Spain. Second, we investigate whether these reforms affected (i) the stability, (ii) the degree of competition, and (iii) lending and liquidity supply of the Spanish banking industry. The main results suggest that the restructuring process reduced the degree of competition but increased financial stability in the Spanish banking industry.

In particular, we find that two divergent forces affected the Spanish financial stability. On the one hand, the bail out dampened financial instability. On the other hand, the increasing bank market power fostered financial stability (i.e., lower risk-taking behaviour). Furthermore, we demonstrate that the restructuring process: (i) increased the Lerner index, (ii) did not increase the collusion among banks (iii) diminished the gap in cost efficiency between weak and healthy banks. Finally, we find that there are not improvements in lending and liquidity supply.
\end{abstract}

Keywords: Bank bail-out, bank restructuring process, financial stability, lending availability, liquidity creation, Boone indicator.

JEL Classification G21 G28 G32 G34

*Acknowledgments: We are very grateful to Giorgio Barba Navaretti, Giacomo Calzolari and Alberto Franco Pozzolo for their invaluable guidance, advice, and encouragement. We are also indebted to Massimiliano Barbi, Gabriella Chiesa, Massimiliano Marzo, Luis Muga, Alireza Naghavi, Rafael Santamaria, and seminar participants at the Department of Economics and the Department of Management of the University of Bologna, and the Business Administration Department of the Public University of Navarra for the helpful feedback and comments. All remaining errors are our own.

${ }^{\dagger}$ Department of Economics, University of Bologna, Piazza Scaravilli 2, 40126 Bologna. Italy. E-mail: pierpaolo.giannoccolo@unibo.it

${ }_{\ddagger}^{\ddagger}$ Department of Economics, Management and Quantitative Methods, University of Milan, Via Conservatorio 7, 20122 Milan. Italy. E-mail: jose.mansilla@unimi.it 


\section{Introduction}

The recent financial crisis has particularly affected the Spanish banking sector, which has experienced accumulated losses of EUR 104,569 million between 2011 and 2012. Several studyes show that not the whole banking industry was equally affected when the crisis became systemic. Although commercial banks and credit unions did not require public support, the crisis was mainly focused on the most part of the savings banks. Notice that, in Spain these saving banks (Cajas de ahorros) are foundations principally controlled de facto by regional governments and received, during the reform process, public financial support subject to a restructuring process of the industry (see Tahoun and van Lent, 2010; Duchin and Sosyura, 2012; Faccio et al., 2006). More precisely, the troubled savings banks were encouraged to be integrated with the healthy ones in form of institutional protection schemes or merged with other healthy financial institutions by the Spanish authorities. Consequently, the number of savings banks were reduced from 45 in 2009 to 10 resultant financial institutions (of which 8 are banks and 2 remain as savings banks) in 2016 (BdE, 2017). The bail-outs were implemented in two phases. Firstly, two savings banks were nationalized: Caja Castilla-La Mancha in March 2009, and Cajasur in May 2010, both with public support. Later on, other 33 savings banks were involved in the process with public financial support amounting to EUR 9.7 billion. Likewise, the Fund for the Orderly Restructuring of the Banking Sector (FROB for its acronym in Spanish) injected capital amounting to EUR 5.7 billion into four banking groups subscribing common shares. The overall capital needs have been significantly reduced owing to burden sharing measures, divestments, and the transfer of problematic assets to the asset management company ('Sociedad de Gestión de Activos procedentes de la Reestructuración Bancaria' SAREB for its acronym in Spanish).

The main purpose of this article is to assess whether these institutional reforms improved the stability of the Spanish banking industry, their impact on credit and liquidity supply for the real sector and how the intensity of competition evolves in this specific industry. From one side, we argue that this Spanish reform is worthy of research in order to test some theoretical predictions given by the literature. In particular, several scholars have outlined that government interventions during systemic banking crises may exacerbate problems of moral hazard because banks may anticipate bail-outs and begin risky businesses (Hakenes and Schnabel, 2010). From the other side, we believe that this is an interesting case study to test the how the competitiveness changes in the banking industry after these kind of reforms. Importantly, since the bailed out institutions were selectively encouraged to be integrated, the Spanish reform is a good opportunity to investigate whether the consolidation process has effectively reduced the degree of competition in the Spanish banking industry, i.e. higher monopoly power. To the best of our knowledge, this study is one of the first attempts to assess the repercussions of finance assistance programmes, i.e. bail-outs, on financial stability and banks' lending supply and liquidity creation, following changes in market structure raised by regulatory interventions as two differentiated transmission mechanisms. 
This research combines bank information from Bureau van Dijk Bankscope and the Table of Public Financial Assistance released by the Bank of Spain. Accurately, our research question is: what has been the trade-off between competitiveness and financial stability?

Regarding the competitiveness, we identify two opposite forces which affect the competitiveness of the Spanish bank industry after the reform. First, we find that the Lerner index has raised again after implementing the restructuring process. This result is normally associated to lower competition in the market. Second, we find that the gap in cost efficiency between troubled financial institutions (weak banks) and healthy banks was diminished as well respect the pre- reform period. This result is normally associated to higher competition in the market. This question is worthy of research since monopoly power has found to increase margins, capital ratios, charter values (Coccorese, 2009), interest rates (Martinez-Miera and Repullo, 2010), and reduce lending availability according to the market power view (e.g. Elsas, 2005; Degryse and Ongena, 2008; Carbó et al., 2009).

As for the financial stability, in line with previous research (e.g. Martinez-Miera and Repullo, 2010; Liu et al., 2013), the results of this study predict that capital injections were not enough to restore financial stability of the overall Spanish banking industry. This result might be driven by the effects of the extension of the sovereign debt crisis in the Eurozone and the upsurge of the crisis between 2011 and 2013 which affected specially to the real sector. In spite of providing a second capital injection -FROB II- and regulatory changes between 2011 and 2012 aimed to intensify the recovery of weak banks, these efforts were not enough to restore financial stability (see BdE, 2017, page 245). Nevertheless, we also find that the reduction in the degree of competition helped banks to increase their ratios of profitability and capitalization.

Furthermore, we find that the volume of risky assets has been reduced after the reform. It is so possible conclude that the Spanish banking market is becoming less heterogeneous due to the selective elimination of weak banks, i.e. less banks but healthier. Notice that this result it is strictly related to the lower gap in cost efficiency between weak and healthy banks. Moreover, our analysis demonstrates that credit and liquidity supply lessened after the restructuring process even though after controlling for demand factors. This result is in line to the credit conditions surveys conducted by the Bank of Spain. These surveys show that the Spanish financial institutions reported a drop in the demand for credit until the end of 2016, contrary to the Eurozone banks, due to the deleveraging process carried out by the private sector.

Finally, our results are consistent with recent research on regulatory interventions and bank performance (e.g. Berger et al., 2016; Buston, 2015; Korte, 2015).

The remainder of the paper proceeds as follows: Section 2 reviews the related literature. Section 3 discusses the precedents of the Spanish banking sector and the restructuring process analysed in this study. Section 4 presents the methodology. Section 5 describes the main results. Section 6 concludes. 


\section{Literature review}

The recent global crisis, one of the most severe since the Great Depression, has been characterized by the large number of failed financial institutions (Acharya et al., 2014). The crisis has shown the importance of having strong mechanisms to allow for the resolution of failed banks (Laeven and Valencia, 2013). The resolution of a financial institution is defined as the restructuring process of the bank in order to recover the continuity of its essential operations, preserve financial stability, and restore the viability of that institution (Gordon and Ringe, 2015). Before the sovereign debt crisis, 'bail-out' approach has been the most frequent regulatory intervention at the bank level used by the governments to restore financial stability (Acharya et al., 2014). ${ }^{1}$

The standard argument is that systemic regulatory policies lead to collective moral hazard problems. This problem arises when banks have access to cheap funding, incentivising them to increase their borrowing and reduce their liquidity. Thus, interventions may have repercussions over the whole financial sector since some banks may play safely, whilst others may start to assume risk (Farhi and Tirole, 2012).

The debate about the repercussions of government interventions in banking markets is still alive. Government interventions have been found to exacerbate problems of moral hazard as banks may anticipate bailouts and reduce market discipline (see Bianchi, 2016; Dam and Koetter, 2012; Flannery, 1998; Hryckiewicz, 2014). During systemic crises, bail-outs contribute to relaxing balance sheet constraints and reducing the severity of the recession. The effects of government interventions on moral hazard can be minimized if bail-outs are systemic and broad-based; but economy may become more vulnerable if interventions are idiosyncratic or targeted (Bianchi, 2016). Dam and Koetter (2012) study moral hazard problems related to bailouts in additional risk taking due to higher bailout non-observable expectations. Political factors may explain bailout probability, but not risk-taking behaviour. They find for a sample of German banks that moral hazard effect is not driven by government-owned or regional savings banks, the so-called Landesbanken. In addition, other authors demonstrate that politically connected institutions are more likely to receive public support (see Tahoun and van Lent, 2010; Duchin and Sosyura, 2012; Faccio et al., 2006). Tahoun and van Lent (2010) show that congressional equity ownership in the private sector affects the extent and the length of government support committed to any firm during the bailout of the financial sector. In addition, Duchin and Sosyura (2012) demonstrate that investment in politically connected firms underperforms unconnected recipients according to both stock-based and accounting performance based measures. Duchin and Sosyura show that a firm whose director served at the Treasury or one of the banking regulators were 9.1 percent more likely to obtain government funding; firms headquartered in the election district of the House members on the key committee were 6.3 percent more likely to be approved. Faccio et al. (2006) show that those politically con-

\footnotetext{
${ }^{1}$ The Directive 2014/59/EU - Banking Recovery and Resolution Directive - introduces the 'bail-in' principle as the resolution mechanism in the EU countries, in substitution of the 'bail-out' principle. The main difference between both resolution mechanisms is that the 'bail-in' put the costs of resolution on creditors of the stressed banks instead of taxpayers.
} 
nected firms exhibit worst financial performance than their unconnected peers at the time of and during the bailout. This evidence demonstrates that political connections may influence allocation of capital through the mechanism of public assistance when firms take on periods of economic distress. ${ }^{2}$ Closely related to this article, Illueca et al. (2014) demonstrate that the rapid expansion of the Spanish saving banks - cajas de ahorros-into regions was partly due to the connection between the board of directors and the same political party as the same region of the bank, and for firms in the real estate and building sectors. As a result, the geographic expansion of the savings banks was associated with ex ante risk-taking behaviour and -ex post default risk. Similarly, Martín-Oliver et al. (2017) demonstrate that the restructuring of insolvent savings banks through intra-regional mergers did not work on this occasion. Political interests at regional levels continued to reduce the resilience in responding to negative shocks.

Several authors advocate that regulatory interventions and capital support may alleviate the consequences of a banking crisis. Theoretical papers predict that regulatory interventions may be a determinant of bank's portfolio risk, since bank's risk-taking behaviour may involve reductions in risky loans or liquidity creation (Mailath and Mester, 1994). Dell'Ariccia and Ratnovski (2013) theoretical model is subject to two sources of risk. The first is idiosyncratic, i.e. dependent on the quality of bank's borrowers, which the bank can control through costly monitoring or screening. The second is the risk of contagion, i.e. exogenous to an individual bank, which has negative effects on the overall real economy, probably triggering a recession. As a result, the 'too-many-to-fail' guarantee may generate strategic complementarity in order to increase bank's likelihood of being bailed out. To prevent this, the regulator should follow a policy of non-rescuing 'systemic' banks in distress, but this policy would not be credible (Acharya and Yorulmazer, 2007, 2008a,b). Bailed-out banks may be perceived as riskier institutions, the so-called stigma channel. Consequently, customers may reduce demand for credit, or become financially constrained; in addition, they may also reduce supply of deposits or charge higher interest rates since these banks are less likely to repay (Berger et al., 2016). Similarly, Helwege et al. (2017) show that most institutions avoided using the Fed's discount window programme, i.e. to be bailed-out, in order not to be considered as an insolvent institution.

Empirical literature on banks' ability to create liquidity, i.e. lending, after regulatory interventions is rapidly growing (Berger et al., 2016; Buston, 2015). Berger et al. (2016) find that regulatory interventions reduce liquidity creation, whilst capital support does not affect liquidity creation. Importantly, they find that capital support contributes to reducing lending as well as bank risk-taking behaviour, whilst regulatory interventions has no effect on lending. Similarly, Buston (2015) show that, although an increase in credit supply may increase banks' risk-taking, it may not be considered detrimental to financial stability if the regulator focuses on proper risk management practices. ${ }^{3}$ Hryckiewicz (2014) analyses several bail-out

\footnotetext{
${ }^{2}$ Sapienza (2004) demonstrates that lending behaviour of state-owned banks, in terms of volume of credit and interest rates charged, is affected by the electoral results of the party affiliated to the bank.

${ }^{3}$ Financial innovation enables banks to isolate financing and investment conditions from shocks. Furthermore, financial innovations may allocate risk in the financial system more efficiently owing to risk may swift to more stable financial institutions (see Froot et al., 1993; Norden et al., 2014).
} 
interventions to find that nationalization and asset management companies contributes to risk the increasing. However, she also do find that under an appropiate combination of policies, government may mitigate the effects on banks' risk. ${ }^{4}$ Accomodating policies, particularly those not well-executed, may dampen credit supply and economic recovery, increase the cost of credit and the risk of moral harzard in the long term (Honohan and Klingebiel, 2003). Diamond and Rajan (2002) shows that bail-out decisions which may generate excess demand for liquidity can create problems of solvency in the banking system, where contagion is spread through the common pool of liquidity.

So far, the common background in the financial literature is that distorted incentives may alter credit allocation and damage real economy performance. This raises the question that which resolution policies may be more effective in recovering the status quo of the financial sector and the real economy (see Khwaja and Mian, 2008; Paravasini, 2008). Diamond and Rajan (2000) demonstrate the importance of designing an adequate program of recapitalization since too small capital injections may encourage perverse lending policies and reduce credit supply for borrowers with valuable investment possibilities. Recently, Laeven and Valencia (2013) demonstrate that bank recapitalization measures may foster credit supply, thus reducing financial frictions in particular for the more dependent non-financial firms. ${ }^{5}$ The real consequences of banks' bail-outs are weaker if bank recapitalization is underestimated, the consequences for the real economy might be undesirable in terms of credit allocation, firm investment, and employment (Giannetti and Simonov, 2013; Guizani and Watanabe, 2016). These results are corroborated by Korte (2015) who demonstrates that a relatively stronger implementation of bank resolution rules increases credit supply by benefiting high quality firm (quality channel), and reallocating credit to firm which need to borrow more (quantity channel). The bank lending channel becomes crucial in the transmission of a shock liquidity to the real sector since high-exposure banks tightened credit than low-exposure banks to non-financial firms (Cingano et al., 2016). Closely related to our research, (Bassett et al., 2017) suggest that U.S. banks which received extraordinary support from five government programs, did not augment credit supply compared to banks that did not. The last findings suggest that lower credit availability has negative consequences for a range of outcomes such as firm value added, investment and employment (Chodorow-Reich, 2014; Bentolila et al., 2017). For the case of Spain, Bentolila et al. (2017) shows the existence of a supply credit shock in the Spanish economy after the beginning of the banking crisis. Using data from the Central Credit Register of the Bank of Spain between 2006 and 2010, Bentolila et al. estimate that around 24\% of the job losses in Spain were given in non-financial firms attached to banks which needed to be recapitalized and restructured by the Bank of Spain and the Fund for the Orderly Restructuring of the Banking Sector (FROB for its acronym in Spanish). This paper extends this literature by evaluating

\footnotetext{
${ }^{4}$ See Honohan (2016) for similar results.

${ }^{5}$ Several authors analysed the effects of 1998 and 1999 capital injection on the Japanese banking system obtaining diverse results. Hoshi and Kashyap (2010) do find that both policies were partially successful in recapitalizing the banks. Montgomery and Shimizutani (2009) and Allen et al. (2011) find that after the 1999 recapitalization programme lending to SMEs was increased, but not under the 1998 programme.
} 
whether the process of banks' resolution in Spain has increased financial stability.

Previous theoretical literature on Industrial Organization applied to the banking industry predicts the existence of a trade-off between competition and financial stability which may encourage policymakers to favour concentration in case of financial crises (Allen and Gale, 2004). On the one hand, the competition-fragility-view advocates that reduction in competition and market power reduce interest margins and the franchise value, leading to an increase in risktaking activities (see IJtsma et al., 2017; Schliephake, 2016). Banks enjoying greater monopoly power are able to look for better lending opportunities and increase margins, capital rations and charter values make them better (see Coccorese, 2004, 2008, 2009). On the other hand, the competition-stability-view predict that banks exhibiting greater monopoly power are able to charge 'uncompetitive' interest rates to their customers, increasing the likelihood of loan defaults, and consequently the risk of portfolios, making the overall banking system less stable (Boyd and De Nicolò, 2005). Empirical literature demonstrate the existence of U-shape relationship between bank concentration and financial stability (e.g. Martinez-Miera and Repullo, 2010; Liu et al., 2013). As far as we are aware, the foremost literature is growing towards the analysis of the effects banking regulation and resolution mechanisms on the competition-stability nexus (see Cummins et al., 2017; Hakenes and Schnabel, 2010; Fu et al., 2014; Schliephake, 2016). In this regard, the Hakenes and Schnabel (2010) theoretical model predicts that bail-outs lead to higher risk-taking amongst the protected bank's competitors. The basic idea is that subsidization induces the 'protected' bank to expand its activities. As a result, the higher competition on the deposit markets will lead to a reduction in bank margins, thus increasing bank-risk taking. Fu et al. (2014) find for a sample of Asian-Pacific banks that bank concentration may foster financial fragility, supporting the neutral view of the competition-stability relationship. Likewise, some banks in the region are able to attain greater discretion in price-setting to increase profits through channels different from market concentration, e.g. product differentiation. Cummins et al. (2017) show that competition increases soundness and contributes to enhancing stability of the EU life insurance industry owing to an increase in efficiency of the overall industry.

\section{Institutional background}

The study of Spain as laboratory is worthy of research. Like other European countries, the Spanish resolution authorities have simultaneously recapitalized troubled banks, set up an asset management companies (e.g. Germany and Ireland), and promoted asset protection schemes -or IPS- (e.g. the UK). The distinction of the Spanish reform is that the bailed-out banks -mostly savings banks- have been selectively encouraged to be integrated amongst themselves or with other healthy banks (see Appendix A), and finally converted into commercial banks. Consequently, the restructuring process has significantly reduced the number of banks, raising market concentration of the banking industry in Spain. This section delves into the main features of the Spanish banking sector before and after the bank restructuring process. The first subsection deals with the conditions which promoted the rapid growth of credit, whilst 
the second subsection explains the main institutional reforms adopted to address the banking crisis.

\subsection{The Spanish banking sector before the crisis}

As of the beginning of the restructuring process in Spain, the banking sector was composed of three pillars: commercial banks, savings banks, and credit unions which differs in terms of ownership amongst them. Firstly, commercial banks are completely owned by their shareholders, composed by nationwide or foreign banks, which operate through the whole domestic territory. Secondly, savings banks were foundations controlled de facto by regional governments, and the Catholic Church in two cases. Consequently, savings banks were less exposed to market discipline than commercial banks, since they were not allowed to issue capital -or to be listed in stock markets-, thus being less able to raise capital (see Bentolila et al., 2017). ${ }^{6} 7$ Finally, credit unions, which are regulated by the Law 13/1989, are aimed at serving the financial need of their shareholders, but also to other customers, are composed by credit cooperatives and professional banks. Unlike the formal differences amongst the three pillars, the Spanish regulatory framework is common for the whole financial institutions.

After the deregulation process in 1985, savings banks expanded considerably their business insofar as the Spanish economy and external financial needs were growing. Similarly, savings banks were gaining market share until equalizing market concentration with commercial banks at the national level, or even they become more relevant in some provinces owing to their links with the territory (Illueca et al., 2014; Martín-Oliver et al., 2017). ${ }^{8}$

The Spanish banking sector were not strongly affected by the impact of the US subprime crisis, but the structural problems of the Spanish economy began to damage the overall industry. Table 1 shows that Construction and Real estate concentrated the most percentage of risk exposure as of 2006. Later on, both sectors also presented the highest growth of non-performing loans from the beginning of the financial crisis in 2007, reaching the absolute maximum in 2013. The data reveal that credit has been re-allocated to Industry and Services, considered safer industry sectors. Moreover, within Services, Real Estate has been gradually losing weight in favour of other sub-sectors such as Financial Intermediation or Other services. Financial stability was gradually damaged insofar as the real sector were affected in form of financial constraints, thus (i) reducing production of goods and services, (ii) increasing the unemployment

\footnotetext{
${ }^{6}$ Savings banks were found to be helpful to avoid social exclusion and financial constrains due to the simplicity of their business and their close link to the territory.

${ }^{7}$ The legal framework of the savings banks was established through the Law 31/1985 of 2nd of August, along with the regulation established by the regional governments after assuming their specific competences according to the Spanish Constitution of 1978 . This Law was repealed by the Law 26/2013 of 27th of December, on savings banks and bank foundations.

${ }^{8}$ Martín-Oliver et al. (2017) show that shortly after the creation of the Euro in which official interest rates were low and abundant liquidity worldwide, banks and cajas migrated to business models more dependent on market debt, despite having different ownership structure. After the crisis in the Euro area, cajas imitated banks in their commercial patters, a usual practice after the above-mentioned liberalization.
} 
rate, and consequently (iii) feeding the volume of non-performing loans (see Figure 1). ${ }^{9}$

Figure 1: Non-performing loans (NPL) ratio and unemployment rate (2002-2016)



Source: Own elaboration based on the Bank of Spain database. The non-performing loans (NPL) ratio is measured as loans to other resident sectors over doubtful loans. The unemployment rate is measured as the percentage of unemployed people actively seeking employment and willing to work over the total labour force. The ratios are reported as a percentage.

This scenario of the overall banking sector affected savings banks more intensively than commercial banks or credit unions ${ }^{10}$, which led to the decline and the transformation of the most part of the savings banks into commercial banks, and triggered the beginning of their resolution process (Funcas, 2015).

\subsection{The implementation of the restructuring process}

The assistance provided by the Spanish authorities during the bank restructuring process can be grouped in five categories: (i) financial assistance disbursed for the recapitalization of banks, (ii) contributions by the Credit Institutions Deposit Guarantee Fund (hereafter FGDEC, for its acronym in Spanish), (iii) guarantees and institutional protection schemes (hereafter IPS), (iv) extraordinary credit lines granted to financial institutions, and (v) contribution to the SAREB, i.e. the asset management company, through the Fund for Orderly Bank Restructuring (hereafter FROB, for its acronym in Spanish).

Since May 2009, the public financial assistance committed in several forms of capital injections amounted to EUR 61,495 million, of which EUR 53,553 million has been provided by

\footnotetext{
${ }^{9}$ Recent studies demonstrate the labour disruptions created by the financial crisis, in particular in those countries with a well-developed financial system, the so-called labour channel. Financial constraints are found to be a catalyst (inhibitor) of job destruction because of firms experience a temporary decline in the demand for their goods, and they will be unable to maintain their employees. In other words, financial constraints amplify fluctuations over employment through the business cycle, particularly for the case of younger firms (see Braun and Larrain, 2005; Pagano and Pica, 2012; McLean and Zhao, 2014; Boustanifar, 2014).

${ }^{10}$ Credit unions usually operate under a low-risk retail banking model.
} 
the FROB and EUR 7,942 million by the banking industry through the FGDEC. At the time of writing this paper, EUR 2,686 million has been recouped, with the stakes of Banco Mare Nostrum and BFA-Bankia still belonging to the FROB, along with the convertible bonds of Banco CEISS and Banco Grupo Caja 3 for a total of EUR 991 million. Secondly, the FROB granted several guarantees to the purchaser to facilitate the sale of the troubled institutions, mainly IPSs. Guarantees totalling EUR 110,895 million have been provided by the State to financial institutions, out of EUR 109,836 million have been cancelled at the time of writing this article. No loss from these guarantees are expected to be assumed by the State (BdE, 2017).

The FGDEC, which was completely funded by the banking industry, provided EUR 7,942 million as assistance to the financial institutions in forms of capital, in addition to the EUR 2,250 million provided in 2009. The FGDEC acquired shares of savings banks, which are unlisted financial institutions, controlled by the FROB which had been obtained from retail investors in the hybrid instrument conversion process for a value of EUR 1,803 million the shares have been sold for a value of EUR 673 million. Other guarantees granted by the FGDEC amount to EUR 390 million. Finally, the FROB has contributed EUR 2,192 million to SAREB (BdE, 2016).

Finally, several consolidation operations were implemented between 2010 and 2016 in forms of IPS, mergers, and integrations with other worthy banks (see Appendix 6). In this process, forty-three out of forty-five savings banks were forced to be converted into commercial banks as a part of the Memorandum of Understanding between Spain and the European Financial Stability Facility which provided financial assistance for the recapitalization of the banking sector (see Bentolila et al., 2017). ${ }^{11}$

\section{Hypotheses, data and methodology}

\subsection{Hypotheses}

The scope of this article is to analyse the effectiveness of the bank restructuring process implemented in Spain between 2010 and 2016 as a consequence of the financial crisis. Based on the theoretical foundations presented above, we formulate the following hypotheses.

Hypothesis 1 (Financial stability) The bank restructuring process improved financial stability.

Hypothesis 2 (Liquidity creation) The bank restructuring process increased liquidity creation.

Hypothesis 3 (Lending availability) The bank restructuring process increased lending availability.

\footnotetext{
${ }^{11}$ Caixa Ontinyent and Colonya Caixa Pollença were not forced to be converted into commercial banks, remaining as the two only savings banks in Spain so far.
} 


\subsection{Data and sample selection}

Bank balance sheet information is provided by Bureau van Dijk Bankscope and Orbis Bank Focus databases. The dataset consists in quarterly information for a sample of Spanish deposittaking institutions for the 2002Q1-2016Q4 period. The sample includes consolidated balance sheets and income statements of commercial banks, savings banks, and credit unions. Several studies on the Spanish banking sector excludes information on credit unions because of these institutions suppose less than the $10 \%$ of total banking assets and their main goal is usually to provide financial services to their associates (Carbó et al., 2007). However, we include them since these institutions started to gain importance in strategic fields such as financial exclusion (e.g. Carbó et al., 2007; Prior et al., 2016), and savings banks have reduced their weight in the final sample after the restructuring process.

We consider that the years selected to perform this analysis are relevant since we are including the years previous to the financial crisis in which banks were granting the highest volume of lending (2002Q1-2007Q2), the period between the beginning of the crisis and the restructuring process (2007Q3-2010Q4), and the years in which the policy implementation was expected to take effect (2011Q1-2016Q4).

Data are expressed in thousands of euros and are inflation adjusted. We also removed nonconsistent values such as zero total assets and zero employees. Finally, we obtain a sample of 3,350 observations for all sample years.

Information of the bank restructuring process is obtained from the Table of Public Financial Assistance released by the Bank of Spain. ${ }^{12}$ The Bank of Spain regularly publishes backnotes on public financial assistance in the restructuring process of the Spanish banking sector. The note also lists the financial institutions which received any financial assistance and the amount of the bail-out received. We use this information to break our sample down between the treated group, or weak banks, if the bank received public financial assistance $\left(W_{i}=1\right)$, and the control group $\left(W_{i}=0\right)$, otherwise. The subscripts $i$ and $t$ refers to banks and periods, respectively. We list the banks classified as weak banks in the first column of Appendix A.1. Table 2 contains the definition and the explanation of the whole variables employed in this article. We winsorize the variables at $1 \%$.

\subsection{Measuring financial stability: The Z-score}

We measure financial stability as the logarithm of the Z-score, which has been extensively used by several authors (e.g. Laeven and Levine, 2009; Schaeck et al., 2012; Liu et al., 2013; Cummins et al., 2017). Using accounting information on bank profitability, its volatility and leverage, the Z-score is defined as follows: ${ }^{13}$

\footnotetext{
${ }^{12}$ Retrieved on the 27th of December 2016 from http://www.frob.es/es/Documents/presbe2016_41en.pdf

${ }^{13}$ Several authors test the robustness of the Z-score by including market-based risk indicators such as the distance-to-default model (e.g. Fu et al., 2014), and the expected default frequency as a forward-looking indicator (e.g. Gulamhussen et al., 2014). Note the reader that savings banks were not entitled to issue capital or to be listed in stock markets, then we only can include accounting-based measures instead of market-based indicators.
} 


$$
Z_{i t}=\frac{R O A_{i t}+C A R_{i t}}{\sigma\left(R O A_{i t}\right)}
$$

where $R O A_{i t}$ represents the return on assets computed as profits (or losses) before taxes over total assets $\left(T A_{i t}\right), C A R_{i t}$ is capital over total assets, and $\sigma\left(R O A_{i t}\right)$ represents the standard deviation of total assets. We use a three-year rolling window for $\sigma\left(R O A_{i t}\right)$ to allow for variability in the denominator and to avoid the Z-score depending exclusively on the variation of profitability and capital cushion.

The Z-score measures the inverse probability of bank's insolvency. A bank becomes insolvent when its asset value is lower than its debt. The Z-score is interpreted as the number of standard deviations that bank's profitability has to fall below its expected value to absorb equity and to make the bank default.

\subsection{Measuring bank market power: The Lerner index}

We use the Lerner index as indicator of banking competition. The Lerner index measures the mark-up between the price and the marginal costs as a percentage of price, being therefore an indicator of the extent of market power. The degree of competition ranges Lerner $_{i t} \in(0,1)$; being Lerner $_{i t}=1$ in case of perfect monopoly, Lerner ${ }_{i t}=0$ in case of perfect competition, and exceptionally Lerner $_{i t}<0$ implies pricing below the marginal costs, thus indicating nonoptimal bank behaviour. The Lerner index is calculated as follows:

$$
\text { Lerner }_{i t}=\frac{P_{i t}-M C_{i t}}{P_{i t}}
$$

where $P_{i t}$ is the ratio of interest income plus other operating income over total assets; and $M C_{i t}$ represents the marginal costs of total assets (see Appendix A.2).

\subsection{Empirical approach}

This section discusses the identification strategy to estimate the impact of the restructuring process of the Spanish banking industry, and the effects of the resultant bank market structure on financial stability, lending availability, and liquidity creation.

Our empirical strategy will be based on the following standard difference-in-differences estimator:

$$
\begin{aligned}
y_{i t} & =\alpha_{0}+\alpha_{1} W_{i}+\alpha_{2} d_{t}+\alpha_{3} W_{i} \times d_{t} \\
& +\alpha_{4} \text { Lerner }_{i t-1}+\alpha_{5} W_{i} \times \text { Lerner }_{i t-1} \\
& +X_{i t-1}^{\prime} \Phi+v_{i}+u_{i t}
\end{aligned}
$$

where the variable $y_{i t}$ is the dependent variable of interest correspondig to the following indicators. Firstly, we employ the logarithm of the Z-score $\left(\ln \left(Z_{i}\right)\right)$ as computed in expression (1). ${ }^{14}$

\footnotetext{
${ }^{14}$ We use the logarithm operator to control for non-linear effects and outliers (see Liu et al., 2013; Cummins
} 
Secondly, we test for the robustness of the results obtained from the logarithm of the Z-score by including the non-performing loans ratio $\left(N P L_{i t}\right)$ defined as the volume of non-performing loans to total loans to customers, and the density ratio compued as as risk-weighted assets over total assets $\left(R W A_{i t} / T A_{i t}\right)$ to checks the robustness of the results. The higher the density ratio, the higher the risks that the bank is taking. Secondly, we use the variable $L O A N T A_{i t}$ to test the effects of the policy implementation on lending availability. Finally, we introduce the ratio liquidity creation over total assets $\left(L C_{i t} / T A_{i t}\right)$. We calculate the bank's $i$ liquidity creation $\left(L C_{i t}\right)$ in thousands of euros following a slight variation of Berger and Bouwman (2009) and Berger et al. (2016) three-step methodology. The components of $L C_{i t}$ are listed in Appendix A.3:

$$
\begin{aligned}
L C_{i t} & =0.5 \times \text { illiquid assets }+0.5 \times \text { liquid liabilities } \\
& -0.5 \times \text { liquid assets }-0.5 \times \text { illiquid liabilities } \\
& -0.5 \times \text { equity }
\end{aligned}
$$

As for the explanatory variables, the variable $W_{i}$ is a one-period-lagged variable dummy which takes the value one if the bank is included in the treatment group, and zero otherwise. The variable $d_{t}$ is a dummy variable which takes the value one after the policy was administered to all the financial institutions listed in Appendix A.1 $(t \geq 2011 Q 1)$, and zero otherwise. The variable Lerner $_{i t-1}$ represents the Lerner index computed as shown in expression (2). The matrix $X_{i t-1}^{\prime}$ is a set of control variables which includes the following one-period-lagged variables. The income structure ratio $\left(I N C_{i t-1}\right)$ is computed as non-interest income over total assets and controls for business diversification. The efficiency ratio $\left(E F F_{i t-1}\right)$ is computed as operating cost over gross income. We also include the dummy variable $M A_{i t-1}$ which takes the value one if the banks has been involved in a process of M\&A, and zero otherwise. In addition, we control for demand factors by including the natural logarithm of the sale prices of dwellings $\left(\operatorname{Ln}\left(H_{t}\right)\right)$.

Since we are also interested in analyzing the effects of bank market power as a result of the restructuring process, we include the interaction term $W_{i} \times \operatorname{Lerner}_{i t-1}$ and $W_{i} \times M A_{i t-1}$. Furthermore, we also add interactions between $W_{i}$ and $X_{i t-1}^{\prime}$ to control for the effects of the policy implementation on each control variable. Besides, the variable crisis $_{t}$ is a crisis dummy which takes the value one if $t>2007 Q 3$ onwards, and zero otherwise, to control for structural breaks. Finally, $v_{i}$ and $u_{i t}$ correspond to bank fixed effects and the regression error term, respectively. We run the OLS estimator with bank fixed effects.

As for the interpretation of expression (3), the parameter of interest are $\alpha_{3}$ which measures the effect of the restructuring process on the dependent variables, and $\alpha_{5}$ which shows the effect of bank market power as a result of the policy implementation testing the hypotheses of this research. The parameter $\alpha_{1}$ control for differences in control and treatment groups, $\alpha_{2}$ shows 
the effects on the dependent variable if the reform would not have been implemented. Finally, the parameter $\alpha_{4}$ benchmarks the results of this research with previous studies which related the effects of bank market structure on financial stability (e.g. IJtsma et al., 2017; Schliephake, 2016) and lending supply (e.g. Berger et al., 2016; Buston, 2015).

\subsection{Theoretical approach}

We consider a simple quantity competition model à la Cournot. Let us assume a homogeneous product market with $n$ banks in which bank $i$ sets $q(i)$. Total output is $Q=q(1)+q(2)+$ $\ldots+q(n)$. The market price is given by the linear inverse demand $p(q)=a-b q$, with $a, b>0$. Let us also suppose that the cost functions are linear and given as $C(i)=c(i) q(i)$, with $c(i) \in[0, a) \forall i=1 \ldots n$. Solving the model for the quantity that bank $i$ produces at the Cournot equilibrium, we obtain:

$$
q(i)^{*}=\frac{a-(n+1) c(i)+\sum_{i \neq j} c(i)}{b(n+1)}
$$

the net effect is generated by the number of banks that remain in the market after the reform, and their cost function.

Evaluated at the equilibrium, the effect on the profit performace of each bank is given by the final quantity and the final price:

$$
\pi(i)^{*}=b\left(q(i)^{*}\right)=\frac{\left(a-(n+1) c(i)+\sum_{i \neq j} c(i)\right)^{2}}{b(n+1)^{2}}
$$

equilibrium profits $\left(\pi(i)^{*}\right)$ decrease with $c(i)$ and increase with $\sum_{i \neq j} c(i)$, which means that lower heterogeneity in the costs function matters. Thus, profits increase when the bank $i$ becomes relatively more efficient than its rivals.

Figure 2 represents the stylised facts of the reform in 2006, 2010, and 2016:

i) Spanish banks became more homogeneous in marginal costs; Figure 2-(a) shows that banks became more cost-efficient after implementing the reform in 2010 (i.e., healthy and weak banks reduced their gap in marginal costs).

ii) Spanish banks became more homogeneous in terms of degree of competition; Figure 2(b) shows that the gap between healthy and weak banks diminished after the policy implementation.

iii) All Spanish banks are involved in the consolidation process; Figure 2-(c) shows that healthy banks also carried out their consolidation process without the need to receive public financial assistance. ${ }^{15}$

\footnotetext{
${ }^{15}$ The restructuring process of weak banks is detailed in Appendix A.1.
} 
Figure 2: Marginal costs, Lerner index, and number of healthy and weak banks (2002, 2007, 2010, 2016)


Source: Own elaboration based on Bankscope, and the Spanish Banking Association (AEB), the Spanish Savings Banks Association (CECA) and the National Union of Credit Cooperatives (UNACC) databases. Subfigure (a) displays marginal costs computed as shown in explained in Appendix A.2. Subfigure (b) represents the Lerner index calculated as shown in expression (2). Subfigure (c) shows the evolution of the number of Spanish banks retrieved from AEB, CECA and UNACC databases.

These stylised facts may be interpreted in the light of the expressions (5) and (6). By using this simple and standard Cournot model, it emerges clearly that the net effect of the Spanish reform in 2010 is generated by two contrasting elements: i) the number of banks (healthy and weak) decreases. Thus, the lower is $n$, the higher is the concentration in the Spanish banking market (i.e., $q(i)^{*}$ and $\pi(i)^{*}$ increase). ii) the gap in marginal costs between Spanish banks is lower. Thus, $\sum_{i \neq j} c(i)-(n+1) c(i)$ decreases (i.e., $q(i)^{*}$ and $\pi(i)^{*}$ decreases).

To sum up, the net degree of competition raised in the Spanish banking industry after the reform, but this net effect is lower than expected due to the two contrasting elements.

\section{Results}

\subsection{Summary statistics and parametric and non-parametric tests}

Table 3 shows the summary statistics of the variables employed in this article. In Panel A we observe that banks' profitability $\left(R O A_{i t}\right)$ has a mean value of 0.3 percent ranging from -4.7 percent to 1.6 percent, while the mean value of bank's capitalization $\left(C A R_{i t}\right)$ has a mean value of 6.7 percent ranging from 2.3 percent to 15.1 percent. Regarding financial stability measures, the logarithm of the Z-score $\left(\operatorname{Ln}\left(Z_{i t}\right)\right)$ shows a mean value of 1.39 ranging from -2.30 to 3.65, the non-performing loans ratio $\left(N P L_{i t}\right)$ displays a mean value of 5.2 , and the density ratio $\left(R W A_{i t} / T A_{i t}\right)$ shows a mean of 0.601 . Regarding lending supply variables, the ratio loans to total assets $\left(L O A N T A_{i t}\right)$ displays a mean value of 0.65 ranging from 0.01 to 0.925 , while the ratio liquidity creation to total assets $\left(L C_{i t} / T A_{i t}\right)$ shows a mean value of 0.31 ranging from -0.21 to 0.90 . The Lerner index $\left(\right.$ Lerner $\left._{i t}\right)$ is the variable of interest, showing a mean value of 0.204 ranging from 0.003 to 0.575 . As for the control variables, the income structure ratio $\left(I N C_{i t}\right)$ shows a mean value of 0.33 ranging from 0.02 to 0.74 , while the efficiency ratio $\left(E F F_{i t}\right)$ shows a mean value of 0.60 ranging from -1.60 to 2.8 . Finally, the logarithm of the sale prices 
of dwellings $\left(\operatorname{Ln}\left(H_{t}\right)\right)$ shows a mean value of 7.40 ranging from 6.96 to 7.65 .

We perform a mean-difference test, as shown in Panel B. In the first step, we create the dummy variable Crisis $_{t}$, which takes the value one from 2007Q3 onwards in order to divide the sample in two sub-periods: before (2002Q1 - 2007Q2) and after (2007Q3 - 2016Q4) the crisis. We show that the parametric test rejects the null $\left(H_{0}: \operatorname{Crisis}_{t}(0)-\operatorname{Crisis}_{t}(1)=0\right)$ for the whole variables except for $L O A N T A_{i t}$. The results further show that the alternative hypothesis is confirmed for $R O A_{i t}$ and $C A R_{i t}\left(H_{0}:\right.$ Crisis $_{t}(0)-$ Crisis $\left._{t}(1)>0\right)$, thus indicating that banks were better performed before the crisis as expected. Accordingly, the alternative hypothesis is also confirmed for the financial stability measure $\left(\operatorname{Ln}\left(Z_{i t}\right)\right)$, as well as the non-performing loans ratio $\left(N P L_{i t}\right)$ which shows its growing path as a consequence of the crisis. Importantly, the test also confirms the alternative hypothesis for the density ratio $\left(R W A_{i t} / T A_{i t}\right)$ indicating that banks have reduced their level or risky assets after the crisis. The other variable of interest is the Lerner index $\left(\right.$ Lerner $\left._{i t}\right)$ which is found to be higher after the financial crisis $\left(H_{0}:\right.$ Crisis $_{t}(0)-$ Crisis $\left._{t}(1)<0\right)$, as well as bank size $\left(\operatorname{Ln}\left(T A_{i t}\right)\right)$ which is shown that after the crisis the volume of bank assets was higher.

To complement the results presented above, we perform a parametric test for comparison of means for weak banks $\left(W_{i}=1\right)$ and healthy banks $\left(W_{i}=0\right)$ for the whole period (2002Q1 2016Q4), before the crisis (2002Q1 - 2007Q2), the quarterlies of the crisis before implementing completely the restructuring process (2007Q3 - 2010Q4), and after the restructuring process (2011Q1 - 2016Q4), as shown in Table 4. We show that the parametric test rejects the null hypothesis $\left(H_{0}: W_{i}(0)-W_{i}(1)=0\right)$ for bank profitability $\left(R O A_{i t}\right)$ for the period before the crisis. However, this difference in profitability between the two groups disappear after the crisis and, ROA continues decreasing on average even after the implementation of the restructuring process, which means that the banking industry became more homogenous. Regarding bank capitalization $\left(C A R_{i t}\right)$ the null is rejected before the crisis being healthy banks more capitalized on average than weak banks. The difference in capitalization is more pronounced between both groups after the crisis. Furthermore, weak banks display lower levels of stability $\left(\operatorname{Ln}\left(Z_{i t}\right)\right)$ and the test rejects the null after the crisis and the implementation of the restructuring process. In line with these results, weak banks display higher levels of non-performing loans $\left(N P L_{i t}\right)$ than healthy banks, and the test rejects the null after the crisis and the policy implementation. Accordingly, weak banks also show higher levels of density ratio $\left(R W A_{i t} / T A_{i t}\right)$ than healthy banks and the test rejects the null for the three subperiods, i.e. before and after the crisis. Regarding lending supply variables, weak banks show higher levels of $L O A N T A_{i t}$ than healthy banks and the test rejects the null for the three subperiods. This result is consistent with Bentolila et al. (2017) who show that the Spanish bailed out banks granted higher volume of credit before the financial crisis. Additionally, these results are also consistent with other authors whom demonstrate the importance of the bank lending channel as an inhibitor of lending provision for high-exposure banks (Cingano et al., 2016). On the other hand, healthy banks display higher levels of liquidity creation $\left(L C_{i t} / T A_{i t}\right)$ on average than weak banks, and the test rejects the null for the subperiods before the crisis (2002Q1 - 2007Q2) and after the 
restructuring process (2011Q1 - 2016Q4) at the 10\% level. As for bank market power ( Lerner $_{i t}$ ), the results show that bank market power is higher before (2002Q1 - 2007Q2) than after the crisis (2007Q3 - onwards). However, note the reader than Lerner ${ }_{i t}$ starts growing after the restructuring process for both groups of banks. Importantly, the parametric test rejects the null hypothesis in favour of the healthy banks which seems to have more capacity to reduce marginal costs.

Table 5 reports the means values of the key variables divided in four quartiles of the Lerner index. The first statistical test reveals that bank profitability $\left(R O A_{i t}\right)$ ranges from 0.004 in the first quartile to 0.008 in the fourth quartile, while variability in profitability $\left(\sigma\left(R O A_{i t}\right)\right)$ also decreases insofar as bank market power increases. Furthermore, the capitalization ratio $\left(C A R_{i t}\right)$ ranges from 0.057 in the first quartile to 0.069 in the fourth quartile. As a result, the indicator of financial stability $\left(\operatorname{Ln}\left(Z_{i t}\right)\right)$ is also increasing in Lerner $_{i t}$ ranging from 1.128 in the first quartile to 1.496 in the fourth quartile. Accordingly, the non-performing loans ratio $\left(N P L_{i t}\right)$ is decreasing in Lerner $_{i t}$ ranging from 0.071 in the first quartile to 0.045 in the fourth quartile, whilst the density ratio $\left(R W A_{i t} / T A_{i t}\right)$ ranges from 0.614 in the first quartile to 0.563 in the fourth quartile. This observation suggest that financial stability variables improve as bank market power increases. Additionally, LOANT $A_{i t}$ ranges from 0.690 in the first quartile to 0.619 in the fourth quartile suggesting that credit supply decreases as bank market power increases. On the other hand, the liquidity ratio $\left(L C_{i t} / T A_{i t}\right)$ ranges from 0.211 in the first quartile to 0.376 in the fourth quartile suggesting that liquidity creation decreases insofar as bank market power increases. Finally, the F overall test rejects the null that the dependent variables are independent of the four quartiles of the Lerner index $\left(H_{0}: \beta_{n \text {-quartile }}=0\right)$ which support the hypothesis that financial stability improves, lending supply increases and liquidity creation decreases insofar as bank market power strengths, measured as the Lerner index.

Finally, Table 6 shows the results of the translog cost function described in Appendix A.2.

\subsection{The effects of the bail-out on financial stability}

The estimations of expression (3) are shown in Table 7. Using the OLS with bank fixed effects estimator, we test whether the intervention of the Spanish national authorities improved the stability of the overall banking system (H-1). The estimation of the parameter $\alpha_{3}$ indicates that one-standard-deviation increase in policy implementation $\left(W_{i} \times d_{t}\right)$ reduces $\operatorname{Ln}\left(Z_{i t}\right)$ by 0.04 percent. We find similar results for the non-performing loans ratio: a one-standard-deviation increase in $W_{i} \times d_{t}$ augments the $N P L_{i t}$ by 0.01 percent in consonance with the results obtained in the previous section. Importantly, we obtain negative and significant sign for $\alpha_{2}$ indicating that in the absence of the bank restructuring process financial stability would have been reduced in 0.08 standard deviations. The estimates for the coefficient $\alpha_{1}$ demonstrates the existence of ex ante differences between weak and healthy banks before the policy implementation. We also observe that a one-standard-deviation increase in $L O A N T A_{i t-1}$ increases $\operatorname{Ln}\left(Z_{i t}\right)$ by 0.12 percent, remaining qualitatively similar after including interaction terms. Accordingly, the res- 
ults show that one-standard-deviation increase in $L O A N T A_{i t-1}$, reduces the non-performing loan ratio by 0.03 percent. The interaction term $L O A N T A_{i t-1} \times W_{i}$ is significant in both cases, suggesting that the restructuring process has favoured improvements in financial stability throughout a reactivation of bank credit to customers. Importantly, the results also reveal that a one-standard-deviation increase in the Lerner index $\left(\operatorname{Lerner}_{i t-1}\right)$ increases $\operatorname{Ln}\left(Z_{i t}\right)$ by 0.02 percent, and similarly the non-performing loans ratio is reduced in 0.01 standard deviations. In addition, we are also interested in analysing the effects of changes in bank market structure due to the restructuring of the banking industry. We find positive and significant sign for the interaction term Lerner $_{i t-1} \times W_{i}$ meaning that the subsequent reduction in the degree of competition as a consequence of the restructuring process increased ex post financial stability. In other words, the reform has reduced the number of financial institutions after eliminating the least efficient ones, thus increasing financial stability. This result is in line with previous authors whom demonstrate that bank competition may increase financial stability as a consequence of capital regulation or resolution mechanisms (e.g. Berger et al., 2016; Hakenes and Schnabel, 2010; IJtsma et al., 2017; Giannetti and Simonov, 2013; Guizani and Watanabe, 2016; Schliephake, 2016).

As for the components of the Z-score $\left(Z_{i t}\right)$, the results shown in Table 8 also confirm that the resulting reduction in the degree of competition increases banks' capitalization $\left(C A R_{i t}\right)$ and profitability $\left(R O A_{i t}\right)$, being the impact in $\alpha_{4}$ and $\alpha_{5}$ higher for the first variable than for the second one. Another important result is that the restructuring process reduces variability in profitability $\left(\sigma\left(R O A_{i}\right)\right)$ even more than the reduction in $R O A_{i}$. We indeed demonstrate the robustness of the previous results: we identify gains in efficiency as the transmission channel through which the reform has improved financial stability of the Spanish banking industry.

The results are also robust after taking into consideration the density ratio $\left(R W A_{i t} / T A_{i t}\right)$ as the dependent variable (Table 10). We observe that a one-standard-deviation increase after the policy implementation $\left(\alpha_{3}\right)$ reduced the density ratio in 0.045 percent. This result means that government interventions reduced the level of risky assets in banks' balance sheet or, in other words, it augmented the levels of financial stability in the overall Spanish banking industry. The results remain qualitatively similar for Lerner $_{i t-1}$ and the interaction term Lerner $_{i t-1} \times W_{i}$, demonstrating the robustness of the results presented above.

\subsection{The effects of the bail-out on liquidity creation and lending avail- ability}

It might be argued that the restructuring process implemented in Spain has modified the organization of the banking industry, and then credit supply and liquidity creation, also called maturity transformation. We test whether the bank restructuring process has affected liquidity creation (H-2) and lending availability (H-3). We report the results in Table 9. The estimation of the parameter $\alpha_{3}$ indicates that one-standard-deviation increase in $W_{i} \times d_{t}$ reduces liquidity creation $\left(L C_{i t} / T A_{i t}\right)$ by 0.035 percent after implementing the restructuring process. Column 
(2) shows that one-standard-deviation increase in Lerner $_{i t-1}$ increases liquidity creation by 0.01 percent. The results are consistent even after including in Columns (2) and (3) financial stability $\left(\operatorname{Ln}\left(Z_{i t-1}\right)\right)$ and the non-performing loans ratio $\left(N P L_{i t-1}\right)$ as regressors following previous empirical research (e.g. Berger et al., 2016). We observe that the entire set of control variables display the expected sign.

The estimates indicate that the restructuring process has not fostered lending availability (Columns (4), (5) and (6)). We conclude that, at least in the short term, an increase in bank market power reduces lending availability $\left(L O A N T A_{i t}\right)$ by $2 \mathrm{pp}$. We also suspected that the re-organization of the banking industry may have played an important role in credit supply. In fact, we also did find an increase in bank market power of the Spanish banks, in particular of the bailed-out ones. Contrary to our expectations, the reduction of the degree of competition is not found to be a determinant of the of the decrease in lending and liquidity creation after the intervention of the Spanish regulatory authorities. Indeed, the results presented in this subsection are consistent with previous research predicting that regulatory interventions -including capital support- do not necessarily improve neither credit supply nor liquidity creation (e.g. Berger et al., 2016; Buston, 2015). Overall, the results presented in this study are also aligned with previous research on industrial organization which advocates that reductions in bank competition may diminish credit supply, creating possible financial restrictions in some cases (see Sapienza, 2002; Ryan et al., 2014; Carbó et al., 2017).

\subsection{Robustness tests: The Boone indicator}

The specifications presented in Table 7 and Table 9 suggest that the resultant bank market power after the implementation of the restructuring process increased financial stability, although the results on liquidity creation and lending supply are inconclusive.

To test the robustness of the results presented above, we estimate in Table 11 and Table 12 five alternative specifications replacing Lerner $_{i t}$ by the Boone (2008) concentration index $\left(B_{t}\right)$. The Boone's indicator is based on the notion that efficient firms -i.e. firms with lower marginal costs- gain profits and market shares. In other words, competition enhances performance of efficient firms and weakens performance of the inefficient ones. The assumption behind the Boone indicator is that bank's products are substitute, and entry costs are low, thus increasing competition in the market (efficiency structure hypothesis). Therefore, 'efficient banks' will take a dominant position in the market with respect to their competitors, and they will increase their profit due to the reduction in marginal cost is faster than increases in prices (see Bolt and Humphrey, 2015; Tabak et al., 2012). Our results are similar to those obtained using the Lerner index. The construction of the (Boone, 2008) concentration index is explained in Appendix A.3. 


\subsection{Discussion of the results}

This study is aimed at disentangling the channels through which the restructuring process affected financial stability, and liquidity and lending supply. The restructuring of the Spanish banking sector was performed through two parallel 'processes': capital injections -or bail-outsand the integration of the weak financial institutions, thus leading to a reduction in the number of competitors.

We benchmark our results with previous research to test the validity of our methodology (see Berger et al., 2016). Regarding government interventions, our results are in line with previous literature predicting that bail-outs may induce banks' risk-taking behaviour, thus reducing financial stability (see Bianchi, 2016; Dam and Koetter, 2012; Flannery, 1998; Hryckiewicz, 2014). Precisely, Table 1 describes that banks' risk patterns are changing. As for the beginning of the crisis, the distribution of credit to the private sector was mostly concentrated in Construction and Real Estate. Afterwards, the banking industry has been moving risks from the above-mentioned sectors to Financial Intermediation -which is a risky sector-, whereas the other sectors did not experienced significant changes.

Besides, summary statistics suggest that the Spanish banking sector experienced a reduction in competition after selectively integrating weak financial institutions. The research question now is which is the resultant force. In other words, what has been the sacrifice in terms of competition for financial stability and lending supply?

According to the literature on Industrial Organization, merging firms, i.e. reducing the number of competitors, may have a twofold effect depending on whether the restructuring process creates more efficient firms, i.e. reducing marginal costs. Let us suppose an industry in which regulatory authorities take banks over without considering improvements in newely banks' cost function, i.e. cost structure does not change with respect to the past. In this case, the reduced number of competitors may well collude to increase prices, as predicted by the structure-conduct-performance hypothesis. On the contrary, resolution authorities may merge financial institutions with the intention of creating economies of scale amongst banks, thus reducing marginal costs: the resulting banks will become more efficient than in the past. According to the efficiency structure hypothesis, efficient banks may gain more market share because they will be able to increase their business volume more quickly than prices.

The results of this study suggest that Spanish banks' marginal costs has significantly reduced after the reform. Spanish banks reduced operating expenses -the number of employees reduced by 26.52 percent from 2010 to 2016, and the number of branches also diminished by 33.23 percent from 2010 to 2016-, and financial expenses (-71.95 percent from 2010 to 2016) during the restructuring process, according to the Bank of Spain's database. Additionally, we do not find empirical evidence of collusive behaviour amongst banks since prices are progressively decreasing, and the estimates of the Boone (2008) indicator are negative for the whole quarters $\left(\beta_{t}<0\right)$. Our results instead suggest that the reduction in the degree of competition is due to gains in efficiency which frames our study within the efficiency structure hypothesis. 
Furthermore, we also do find that the Spanish resolution authorities minded the gap in marginal costs between weak and healthy banks. As a result, the Spanish banking industry become more homogeneous and stable due to the selective integration of banks. In this regard, the regression estimates corroborate that the reduction in competition enhanced financial stability in Spain in line with the competition-fragility-view (see IJtsma et al., 2017; Schliephake, 2016).

In line with previous research (Bassett et al., 2017), our findings suggest that banks participating in the restructuring process did not improved lending supply compared to banks that did not. This result might be driven by two factors. Firstly, the Spanish private sector is performing a deleveraging process which reduced the demand for credit until the end of 2016 (BdE, 2017). Finally, the supply analysis do not report evidence that neither liquidity creation nor the volumen of credit approached the monopoly optimal quantity. However, it is fair to say that loan portfolio composition reveals significant changes of risk orientation, shifting from Construction and Real Estate to Financial intermediation from 2007 onwards (Table 1).

To sum up, the findings of this study are relevant for economic literature because it demonstrates that the success of a restructuring process depends on whether the resolution authorities help newly created banks to decrease marginal costs in order to enhance the efficiency of the overall industry, and tailor tailor a more homogeneous costs (i.e. less efficient banks converge to the best ones).

\section{Conclusions}

This article analyses the effectiveness of the bail-out and the integration policy implemented in Spain between 2010 and 2014 as a consequence of the financial crisis. To this purpose, we combine data from Bureau van Dijk Bankscope, Orbis Bank Focus, and the Bank of Spain's Table of Public Financial Assistance.

The results of this study draw the conclusion that the bail-out, along with the integration process undertaken as a part of the Memorandum of Understanding (see Section 3), improved the stability of the overall Spanish banking industry. The Spanish resolution authorities simultaneously invited to weak banks to be integrated amongst them in form of IPSs, and in other cases, healthy banks took other weak banks over, leading to an increase in concentration of the banking industry (see BdE, 2017). Thus, the question to be addressed is whether it has been translated into higher levels of market power and, if so, to search evidence of repercussions for credit and liquidity supply as predicted by previous research. We do find that the restructuring process indeed leads to an increase in the Lerner index for the Spanish banks, and this effect has been also responsible of the improvement in financial stability by increasing profits, capitalization, and reducing differences in profitability amongst banks. However, we do not find clear evidence for liquidity creation and lending availability. 


\section{References}

Acharya, V., I. Drechler, and P. Schnabl (2014). A pyrrhic victory? Bank bailouts and sovereign credit risk. The Journal of Finance 69(6), 2689-2739.

Acharya, V. V. and T. Yorulmazer (2007). Too many to fail - an analysis of time-inconsistency in bank closure policies. Bank of England Working Paper no. 139.

Acharya, V. V. and T. Yorulmazer (2008a). Cash-in-the-market pricing and optimal resolution of bank failures. Review of Financial Studies 21(6), 2705-2742.

Acharya, V. V. and T. Yorulmazer (2008b). Information contagion and bank herding. Journal of Money, Credit and Banking 40(1), 215-231.

Allen, F. and D. Gale (2004). Competition and financial stability. Journal of Money, Credit and Banking 36(3), $453-480$.

Allen, L., S. Chakraborty, and W. Watanabe (2011). Foreign direct investment and regulatory remedies for banking crises: Lessons from Japan. Journal of International Business Studies 42(7), 875-893.

Bassett, W., S. Demiralp, and N. Lloyd (2017). Government support of banks and bank lending. Journal of Banking Finance.

BdE (2016). Background note on public financial assistance in the restructuring of the Spanish banking sector (2009-2016). Bank of Spain (BdE) and FROB. 6th of September 2016.

BdE (2017). Report on the financial and banking crisis in spain, 2008-2014. Bank of Spain (BdE). May 2017.

Bentolila, S., M. Jensen, and G. Jiménez (2017). When credit dries up: Job losses in the great recession. Journal of the European Economic Association, forthcoming.

Berger, A. N. and C. H. Bouwman (2009). Bank liquidity creation. Review of Financial Studies 22(9), 37793837.

Berger, A. N., C. H. Bouwman, T. Kick, and K. Schaeck (2016). Bank liquidity creation following regulatory interventions and capital support. Journal of Financial Intermediation 26, 115 - 141.

Berger, A. N., R. A. Roman, and J. Sedunov (2016). Do bank bailouts reduce or increase systemic risk? The effects of TARP on financial system stability. The Federal Reserve Bank of Kansas City Research Working Paper 16-08.

Bianchi, J. (2016, December). Efficient bailouts? American Economic Review 106(12), 3607-59.

Birchwood, A., M. Brei, and D. M. Noel (2017). Interest margins and bank regulation in central america and the caribbean. Journal of Banking Finance 85, 56-68.

Bolt, W. and D. Humphrey (2015). Assessing bank competition for consumer loans. Journal of Banking Finance 61, $127-141$.

Boone, J. (2008). A new way to measure competition*. The Economic Journal 118(531), 1245-1261.

Boustanifar, H. (2014). Finance and employment: Evidence from U.S. banking reforms. Journal of Banking Finance 46, $343-354$.

Boyd, J. H. and G. De Nicolò (2005). The theory of bank risk taking and competition revisited. The Journal of Finance 60(3), 1329-1343.

Braun, M. and B. Larrain (2005). Finance and the business cycle: International, inter-industry evidence. The Journal of Finance 60(3), 1097-1128.

Buston, C. S. (2015). Active risk management and banking stability. Journal of Banking 83 Finance forthcoming.

Carbó, S., E. P. M. Gardener, and P. Molyneux (2007). Financial exclusion in Europe. Public Money 83 Management 27(1), 21-27. 
Carbó, S., D. B. Humphrey, and R. López del Paso (2007). Opening the black box: Finding the source of cost inefficiency. Journal of Productivity Analysis 27(3), 209-220.

Carbó, S., J. M. Mansilla, and F. Rodríguez (2017). The effects of bank market power in short-term and longterm firm credit availability and investment. Spanish Journal of Finance and Accounting / Revista Española de Financiación y Contabilidad 46(1), 1-27.

Carbó, S., F. Rodríguez, and G. F. Udell (2009). Bank market power and sme financing constraints. Review of Finance 13(2), 309-340.

Chodorow-Reich, G. (2014). The employment effects of credit market disruptions: Firm-level evidence from the 20089 financial crisis. The Quarterly Journal of Economics 129(1), 1-59.

Cingano, F., F. Manaresi, and E. Sette (2016). Does credit crunch investment down? New evidence on the real effects of the bank-lending channel. Review of Financial Studies 29(10), 2737-2773.

Coccorese, P. (2004). Banking competition and macroeconomic conditions: a disaggregate analysis. Journal of International Financial Markets, Institutions and Money 14(3), 203 - 219.

Coccorese, P. (2008). Bank competition and regional differences. Economics Letters 101(1), 13 - 16.

Coccorese, P. (2009). Market power in local banking monopolies. Journal of Banking Finance 33(7), 11961210.

Cummins, J. D., M. Rubio-Misas, and D. Vencappa (2017). Competition, efficiency and soundness in European life insurance markets. Journal of Financial Stability 28, 66 - 78.

Dam, L. and M. Koetter (2012). Bank bailouts and moral hazard: Evidence from Germany. Review of Financial Studies 25(8), 2343-2380.

Degryse, H. and S. Ongena (2008). \{CHAPTER 15 - competition and regulation in the banking sector: A review of the empirical evidence on the sources of bank rents. In A. V. Thakor, , and A. W. Boot (Eds.), Handbook of Financial Intermediation and Banking, Handbooks in Finance, pp. 483 - 554. San Diego: Elsevier.

Dell'Ariccia, G. and L. Ratnovski (2013). Bailouts and systemic insurance. IMF Working Paper WP/13/233.

Diamond, D. W. and R. G. Rajan (2000). A theory of bank capital. The Journal of Finance 55(6), 2431-2465.

Diamond, D. W. and R. G. Rajan (2002). Bank bailouts and aggregate liquidity. The American Economic Review 92(2), 38-41.

Duchin, R. and D. Sosyura (2012). The politics of government investment. Journal of Financial Economics $106(1), 24-48$.

Elsas, R. (2005). Empirical determinants of relationship lending. Journal of Financial Intermediation 14(1), $32-57$.

Faccio, M., R. W. Masulis, and J. J. McConnell (2006). Political connections and corporate bailouts. The Journal of Finance 61(6), 2597-2635.

Farhi, E. and J. Tirole (2012, February). Collective moral hazard, maturity mismatch, and systemic bailouts. American Economic Review 102(1), 60-93.

Flannery, M. J. (1998). Using market information in prudential bank supervision: A review of the U.S. empirical evidence. Journal of Money, Credit and Banking 30(3), 273-305.

Froot, K. A., D. S. Scharfstein, and J. C. Stein (1993). Risk management: Coordinating corporate investment and financing policies. The Journal of Finance 48(5), 1629-1658.

Fu, X. M., Y. R. Lin, and P. Molyneux (2014). Bank competition and financial stability in Asia Pacific. Journal of Banking Finance 38, $64-77$.

Fu, X. M., Y. R. Lin, and P. Molyneux (2016). Bank capital and liquidity creation in Asia Pacific. Economic Inquiry 54(2), 966-993. 
Funcas (2015). El nuevo mapa de las fundaciones: de cajas de ahorros a fundaciones. Technical report, Fundación de las Cajas de Ahorros. Madrid. Spain.

Giannetti, M. and A. Simonov (2013, January). On the real effects of bank bailouts: Micro evidence from japan. American Economic Journal: Macroeconomics 5(1), 135-67.

Gordon, J. N. and J. N. Ringe (2015). Bank resolution in the european banking union: A transatlantic perspective on what it would take. Columbia Law Review 115(5), 1297-1369.

Guizani, B. and W. Watanabe (2016). The effects of public capital infusions on banks' risk-shifting to the deposit insurance system in Japan. Journal of Financial Stability 26, 15 - 30.

Gulamhussen, M., C. Pinheiro, and A. F. Pozzolo (2014). International diversification and risk of multinational banks: Evidence from the pre-crisis period. Journal of Financial Stability 13, 30 - 43.

Hakenes, H. and I. Schnabel (2010). Banks without parachutes: Competitive effects of government bail-out policies. Journal of Financial Stability 6(3), 156 - 168.

Helwege, J., N. M. Boyson, and J. Jindra (2017). Thawing frozen capital markets and backdoor bailouts: Evidence from the Fed's liquidity programs. Journal of Banking Finance 76, 92 - 119.

Honohan, P. (2016). Debt and austerity: Post-crisis lessons from Ireland. Journal of Financial Stability 24, 149 $-157$.

Honohan, P. and D. Klingebiel (2003). The fiscal cost implications of an accommodating approach to banking crises. Journal of Banking Finance 27(8), 1539 - 1560.

Hoshi, T. and A. K. Kashyap (2010). Will the U.S. bank recapitalization succeed? Eight lessons from Japan. Journal of Financial Economics 97(3), 398-417. The 2007-8 financial crisis: Lessons from corporate finance.

Hryckiewicz, A. (2014). What do we know about the impact of government interventions in the banking sector? An assessment of various bailout programs on bank behavior. Journal of Banking Finance 46, $246-265$.

IJtsma, P., L. Spierdijk, and S. Shaffer (2017). The concentrationâstability controversy in banking: New evidence from the eu-25. Journal of Financial Stability.

Illueca, M., L. Norden, and G. F. Udell (2014). Liberalization and risk-taking: Evidence from governmentcontrolled banks. Review of Finance 18(4), 1217-1257.

Khwaja, A. I. and A. Mian (2008, September). Tracing the impact of bank liquidity shocks: Evidence from an emerging market. American Economic Review 98(4), 1413-42.

Korte, J. (2015). Catharsis - The real effects of bank insolvency and resolution. Journal of Financial Stability 16, $213-231$.

Laeven, L. and R. Levine (2009). Bank governance, regulation and risk taking. Journal of Financial Economics $93(2), 259-275$.

Laeven, L. and F. Valencia (2013). The real effects of financial sector interventions during crises. Journal of Money, Credit and Banking 45(1), 147-177.

Liu, H., P. Molyneux, and J. O. S. Wilson (2013). Competition and stability in European banking: A regional analysis*. The Manchester School 81(2), 176-201.

Mailath, G. J. and L. J. Mester (1994). A positive analysis of bank closure. Journal of Financial Intermediation 3(3), $272-299$.

Martín-Oliver, A., S. Ruano, and V. Salas-Fumás (2017). The fall of spanish cajas: Lessons of ownership and governance for banks. Journal of Financial Stability.

Martinez-Miera, D. and R. Repullo (2010). Does competition reduce the risk of bank failure? Review of Financial Studies 23(10), 3638-3664. 
McLean, R. D. and M. Zhao (2014). The business cycle, investor sentiment, and costly external finance. The Journal of Finance $69(3), 1377-1409$.

Montgomery, H. and S. Shimizutani (2009). The effectiveness of bank recapitalization policies in Japan. Japan and the World Economy 21(1), 1 - 25.

Norden, L., C. S. Buston, and W. Wagner (2014). Financial innovation and bank behavior: Evidence from credit markets. Journal of Economic Dynamics and Control 43, 130 - 145. The Role of Financial Intermediaries in Monetary Policy Transmission.

Pagano, M. and G. Pica (2012). Finance and employment. Economic Policy 27(69), 5-55.

Paravasini, D. (2008). Local bank financial constraints and firm access to external finance. The Journal of Finance 63(5), 2161-2193.

Prior, D., E. Tortosa-Ausina, M. P. García-Alcober, and M. Illueca (2016). Costs, revenues and performance in Spanish banking: a comparative analysis of pre- and early crisis years. Spanish Journal of Finance and Accounting / Revista Española de Financiaciación y Contabilidad 45(3), 345-364.

Ryan, R. M., C. M. O'Toole, and F. McCann (2014). Does bank market power affect SME financing constraints? Journal of Banking \& Finance 49, 495 - 505.

Sapienza, P. (2002). The effects of banking mergers on loan contracts. The Journal of Finance 57(1), 329-367.

Sapienza, P. (2004). The effects of government ownership on bank lending. Journal of Financial Economics 72(2), $357-384$.

Schaeck, K., M. Cihak, A. Maechler, and S. Stolz (2012). Who disciplines bank managers? Review of Finance $16(1), 197-243$.

Schliephake, E. (2016). Capital regulation and competition as a moderator for banking stability. Journal of Money, Credit and Banking 48(8), 1787-1814.

Tabak, B. M., D. M. Fazio, and D. O. Cajueiro (2012). The relationship between banking market competition and risk-taking: Do size and capitalization matter? Journal of Banking Finance 36(12), 3366 - 3381. Systemic risk, Basel III, global financial stability and regulation.

Tahoun, A. and L. van Lent (2010). Personal wealth interests of politicians and government intervention in the economy: The bailout of the U.S. financial sector. Mimeo. 


\section{Appendix A}

\section{A.1 The Spanish bank restructuring process in 2006, 2010, and 2016}

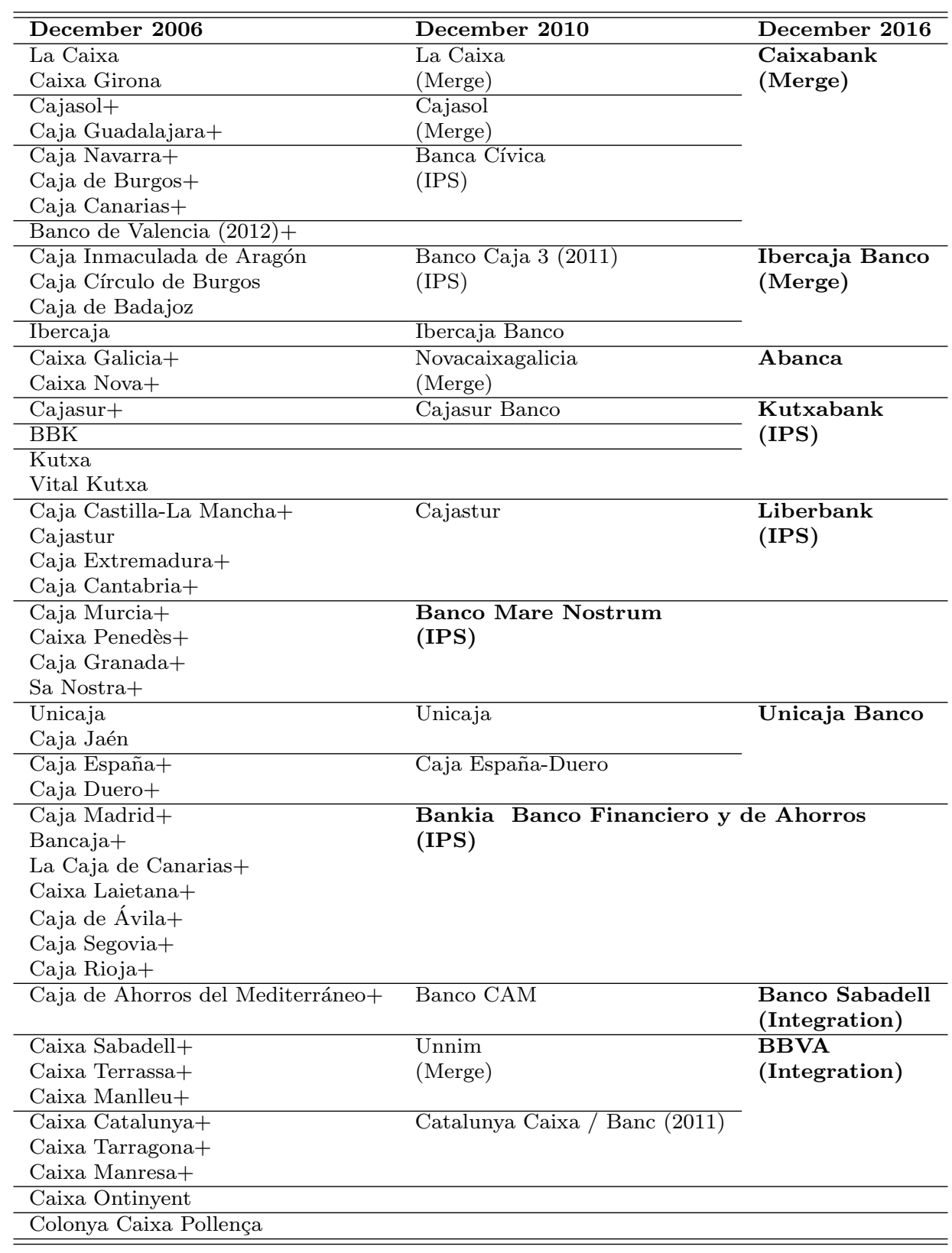

Notes: Own elaboration based on the Table of Public Financial Assistance, Bank of Spain. The + symbol denotes the financial institutions taken into consideration as weak banks $\left(W_{i}=1\right)$ in our analysis. The second and the third columns list the resulting banks in December 2010 and December 2014. The acronym IPS refers to Institutional Protection Scheme. 


\section{A.2 Calculating the marginal costs}

The computation of the marginal costs $\left(M C_{i t}\right)$ shown in expression 2 is based on the following transcendental logarithmic cost function (see Birchwood et al., 2017; Carbó et al., 2017):

$$
\begin{aligned}
\ln \left(C_{i t}\right) & =\delta_{0}+\delta_{1} \ln \left(T A_{i t}\right)+\frac{\delta_{2}}{2}\left(\ln \left(T A_{i t}\right)\right)^{2}+\sum_{h=1}^{3} \beta_{h} \ln \left(w_{h i t}\right) \\
& +\frac{1}{2} \sum_{h=1}^{3} \sum_{k=1}^{3} \beta_{h k} \ln \left(w_{h i t}\right) \times \ln \left(w_{k i t}\right)+\frac{1}{2} \sum_{h=1}^{3} \gamma_{h} \ln \left(T A_{i t}\right) \times \ln \left(w_{h i t}\right) \\
& +\mu_{1} \text { Trend }+\mu_{2} \frac{1}{2} \text { Trend }^{2}+\mu_{3} \text { Trend } \times \ln \left(T A_{i t}\right) \\
& +\sum_{h=1}^{3} \lambda_{h} \text { Trend } \times \ln \left(w_{h i t}\right)+\ln \left(u_{i t}\right)
\end{aligned}
$$

where $C_{i t}$ represents the total costs (including operating and financial costs), and $w_{i t}$ the cost of inputs (labour, capital, and deposits). The variable Trend is included to control for technological changes over time. A system of factor (share) equations is derived according to the Shephard's lemma:

$$
\frac{\partial \ln \left(C_{i t}\right)}{\partial \ln \left(w_{h i t}\right)}=m_{h i t}=\beta_{h}+\sum_{h=1}^{3} \beta_{k} \ln \left(w_{k i t}\right)+\frac{\gamma_{h}}{2} \ln \left(T A_{i t}\right)+\lambda_{h} \text { Trend }
$$

where $m_{\text {hit }}$ represents the cost share of factor $h$ for bank $i$ in period $t$.

\section{A.3 Calculating the Boone (2008) concentration index}

The estimation of the Boone (2008) concentration index -indicator- is based on the following equation, where we interact the Boone indicator with time dummies $\left(D_{t}\right)$ to assess the time evolution of competition:

$$
\ln \left(M S_{i l t}\right)=\alpha+\sum_{t=2002 Q 2-2016 Q 4} \beta_{t} D_{t} \ln \left(M C_{i l t}\right)+D_{t}+e_{i l t}
$$

where $M S_{i l t}$ represents the market share for loans, and $M C_{i l t}$ the marginal costs of the loan market $(l)$ for bank $i$ at time $t$. The estimation of the Boone (2008) indicator for each period $t$ is the result of this regression. The interpretation of the parameter $\beta$ proceeds as follows. Banks with lower marginal costs are expected to gain market shares, then a more negative beta indicates higher competition levels. Contrarily, positive values of $\beta$ indicates that the market has elevate levels of collusion. We create the variable $B_{t}$ as a vector of the estimates of $\beta_{t}$. 


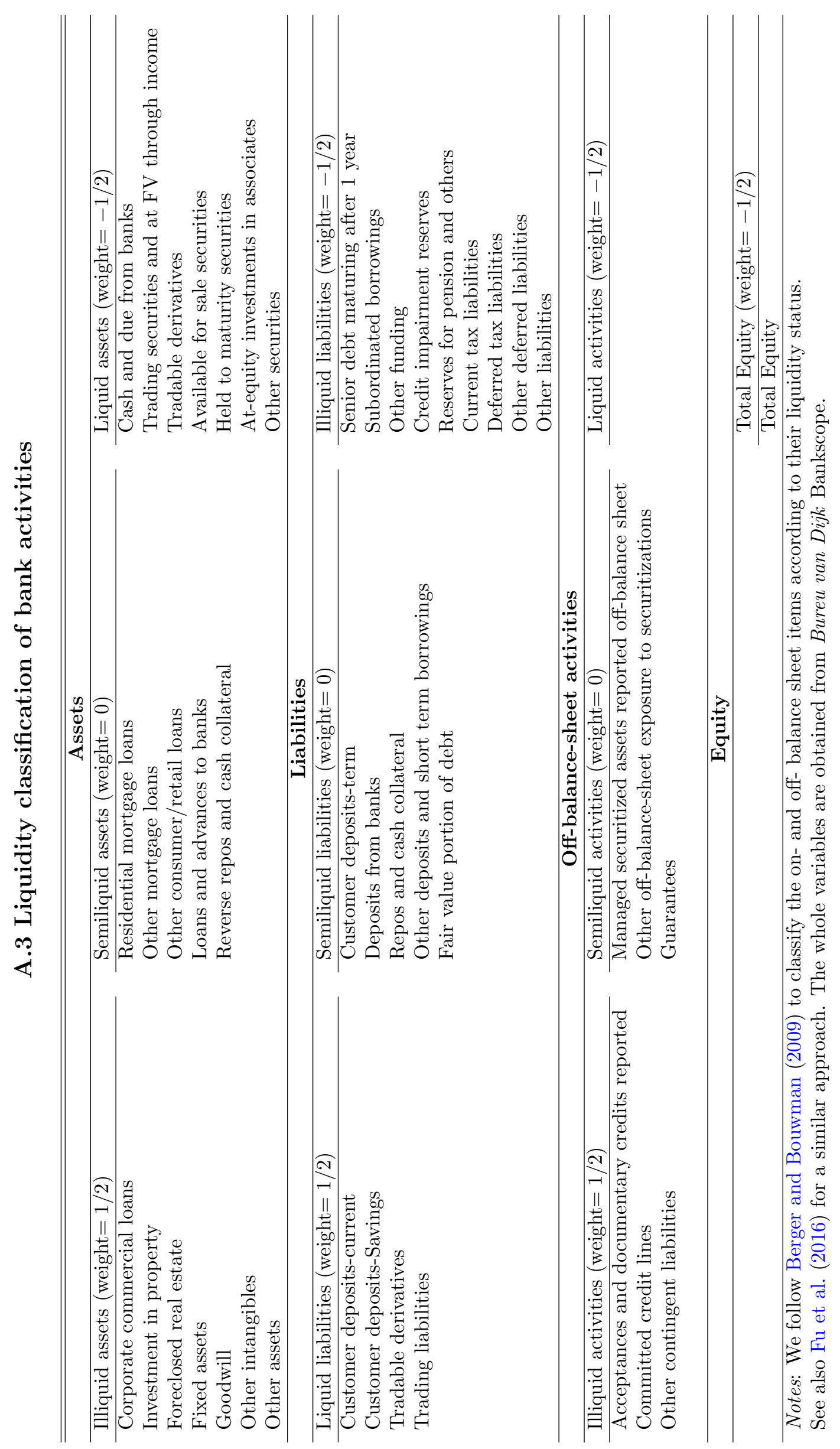




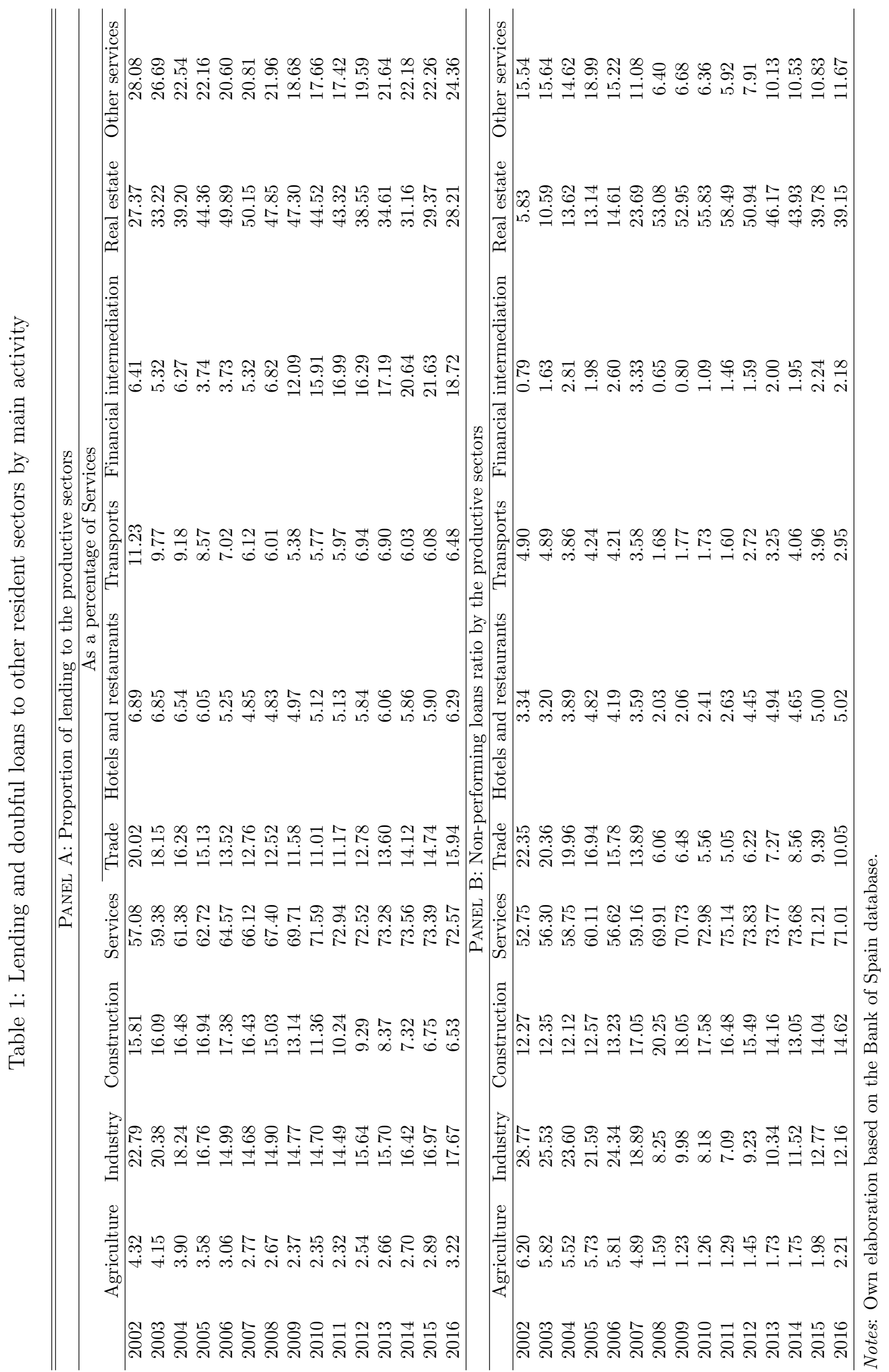




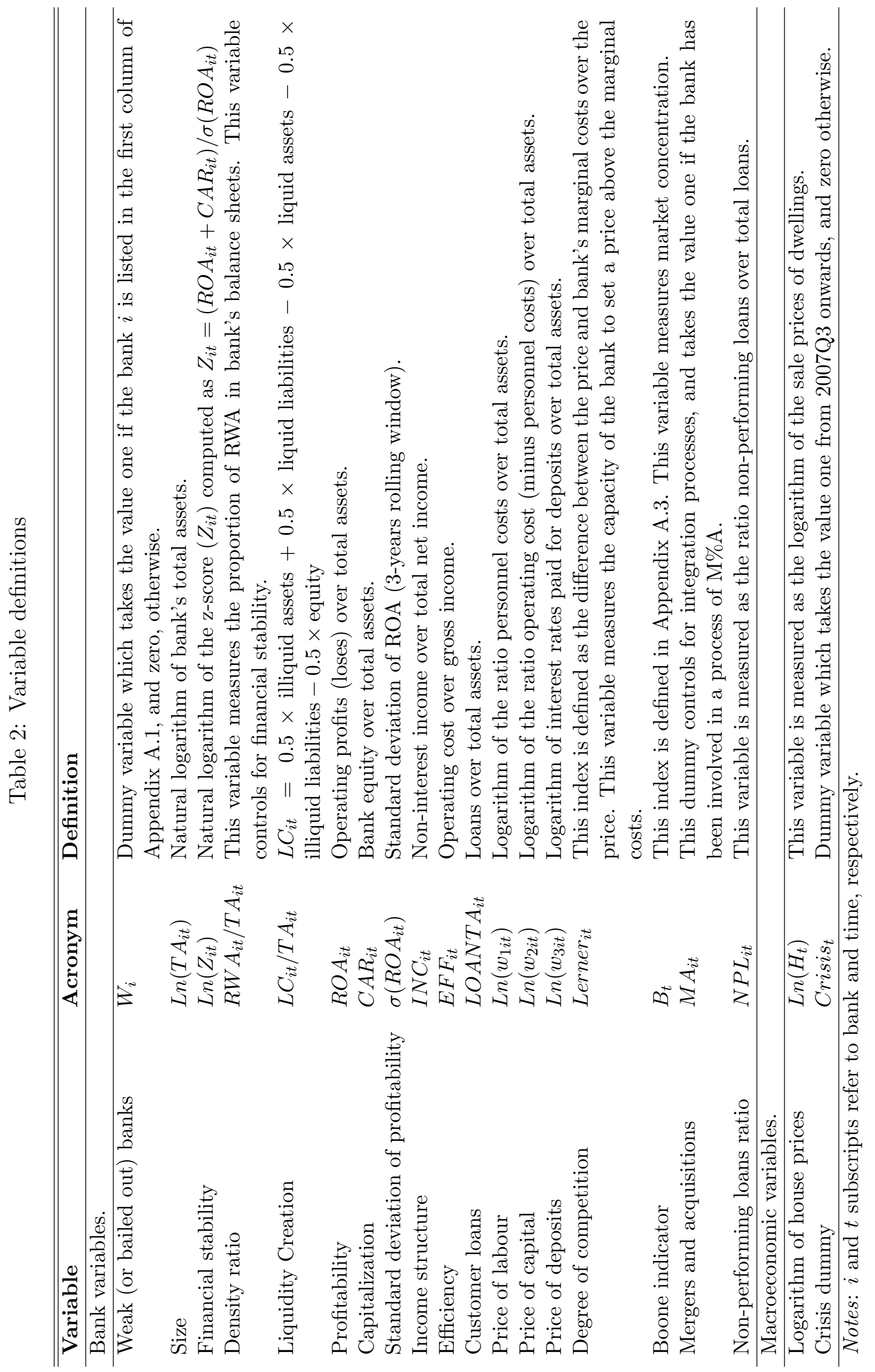




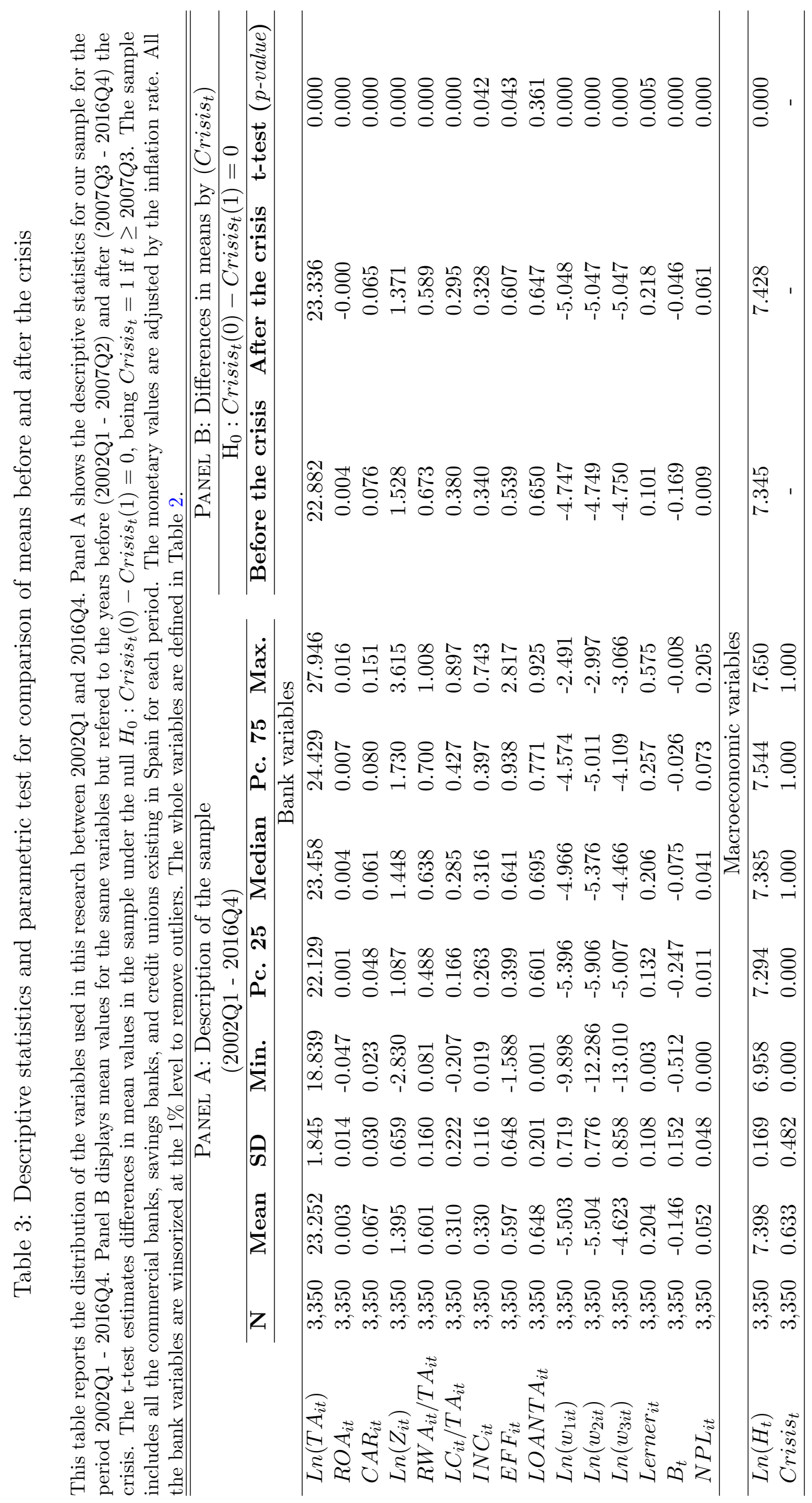




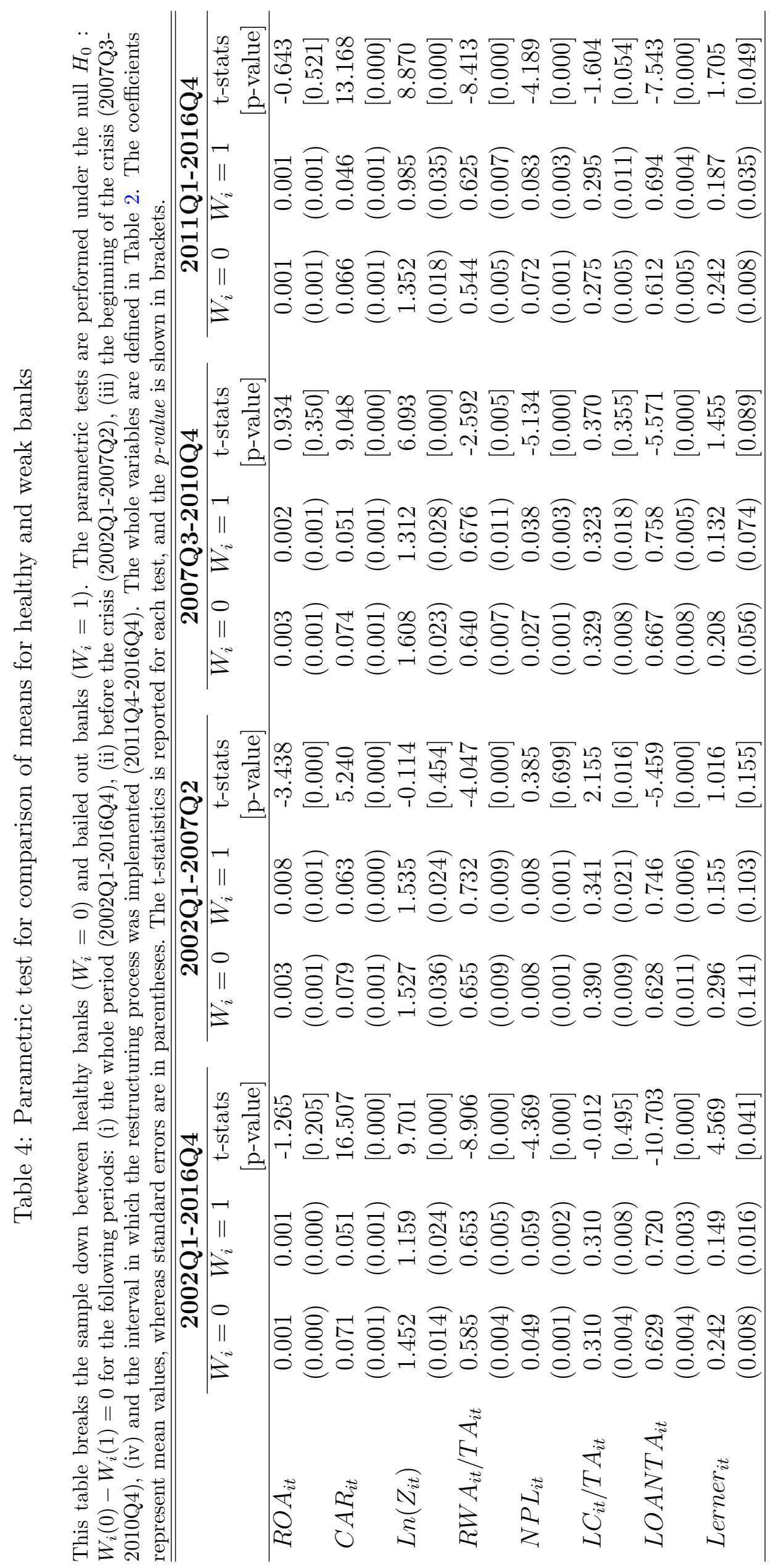


Table 5: Means of the key variables depending on quartiles of Lerner $_{i t}$ (2002Q1 - 2016Q4)

This table displays the summary statistics of the dependent variables employed in this study by quartiles of the Lerner index. The regression coefficients represent the mean value of the variable, whilst the standard errors are represented in parentheses. All specifications are estimated using OLS. The whole variables are defined in Table 2. The F-statistics are shown to test the differences in the dependent variables amongst the quartiles of Lerner $_{i t}$, and the $p$-value is represented in brackets. Estimates followed by $*,{ }^{* *},{ }^{* * *}$ are statistically significant at the 10,5 and $1 \%$ level, respectively.

\begin{tabular}{lccccc}
\hline \hline & 1st Quartile & 2nd Quartile & 3rd Quartile & 4th Quartile & F-test \\
\hline$R O A_{i t}$ & $0.004^{* * *}$ & $0.005^{* * *}$ & $0.006^{* * *}$ & $0.008^{* * *}$ & 39.29 \\
& $(0.001)$ & $(0.001)$ & $(0.001)$ & $(0.001)$ & {$[0.000]$} \\
$C A R_{i t}$ & $0.057^{* * *}$ & $0.063^{* * *}$ & $0.064^{* * *}$ & $0.069^{* * *}$ & $1,470.00$ \\
& $(0.002)$ & $(0.002)$ & $(0.002)$ & $(0.002)$ & {$[0.000]$} \\
$\sigma\left(R O A_{i t}\right)$ & $0.019^{* * *}$ & $0.018^{* * *}$ & $0.017^{* * *}$ & $0.016^{* * *}$ & 712.83 \\
& $(0.001)$ & $(0.001)$ & $(0.001)$ & $(0.001)$ & {$[0.000]$} \\
$L n\left(Z_{i t}\right)$ & $1.128^{* * *}$ & $1.391^{* * *}$ & $1.405^{* * *}$ & $1.496^{* * *}$ & $1,459.82$ \\
& $(0.035)$ & $(0.035)$ & $(0.035)$ & $(0.035)$ & {$[0.000]$} \\
$N P L_{i t}$ & $0.071^{* * *}$ & $0.056^{* * *}$ & $0.047^{* * *}$ & $0.045^{* * *}$ & $1,014.30$ \\
& $(0.002)$ & $(0.002)$ & $(0.002)$ & $(0.002)$ & {$[0.000]$} \\
$L C_{i t} / T A_{i t}$ & $0.211^{* * *}$ & $0.256^{* * *}$ & $0.291^{* * *}$ & $0.376^{* * *}$ & 788.45 \\
& $(0.010)$ & $(0.010)$ & $(0.010)$ & $(0.010)$ & {$[0.000]$} \\
& $0.690^{* * *}$ & $0.686^{* * *}$ & $0.683^{* * *}$ & $0.619^{* * *}$ & $4,016.68$ \\
& $(0.011)$ & $(0.011)$ & $(0.011)$ & $(0.011)$ & {$[0.000]$} \\
$R W A_{i t}$ & $0.614_{i t}^{* * *}$ & $0.613^{* * *}$ & $0.596^{* * *}$ & $0.563^{* * *}$ & $3,801.35$ \\
& $(0.009)$ & $(0.009)$ & $(0.009)$ & $(0.009)$ & {$[0.000]$} \\
\hline
\end{tabular}


Table 6: Translog cost function coefficient estimates.

This table provides the SUR estimation of the translog cost function. Cost shares are the predicted costs spent on each input. The dependent variable is the logarithm of bank's total assets. The whole variables are defined in Table 2. Standard errors in parenthesis are clustered at the bank level. Estimates followed by $*, * *, * * *$ are statistically significant at the 10,5 and $1 \%$ level, respectively.

\begin{tabular}{lcc}
\hline \hline & Coefficient & Standard error \\
\hline Intercept & $-4.4241^{* * *}$ & 0.7467 \\
$\operatorname{Ln}\left(T A_{i t}\right)$ & $1.2832^{* * *}$ & 0.0549 \\
$\operatorname{Ln}\left(T A_{i t}\right)^{2}$ & $-0.0044^{* * *}$ & 0.0003 \\
$\operatorname{Ln}\left(w_{1 i t}\right)$ & $1.1414^{* * *}$ & 0.2124 \\
$\operatorname{Ln}\left(w_{2 i t}\right)$ & $0.6650^{* * *}$ & 0.1803 \\
$\operatorname{Ln}\left(w_{3 i t}\right)$ & $1.881^{* * *}$ & 0.1151 \\
$\operatorname{Ln}\left(w_{1 i t}\right)^{2}$ & $0.1552^{* * *}$ & 0.0032 \\
$\operatorname{Ln}\left(w_{2 i t}\right)^{2}$ & $0.1469^{* * *}$ & 0.0064 \\
$\operatorname{Ln}\left(w_{3 i t}\right)^{2}$ & $0.0187^{* * *}$ & 0.0025 \\
$\operatorname{Ln}\left(w_{1 i t}\right) \times \operatorname{Ln}\left(w_{2 i t}\right)$ & $0.1033^{* * *}$ & 0.0024 \\
$\operatorname{Ln}\left(w_{1 i t}\right) \times \operatorname{Ln}\left(w_{3 i t}\right)$ & $0.4324^{* * *}$ & 0.0201 \\
$\operatorname{Ln}\left(w_{2 i t}\right) \times \operatorname{Ln}\left(w_{3 i t}\right)$ & $0.0188^{* * *}$ & 0.0025 \\
$\operatorname{Ln}\left(w_{1 i t}\right) \times \operatorname{Ln}\left(T A_{i t}\right)$ & $0.0430^{* *}$ & 0.0174 \\
$\operatorname{Ln}\left(w_{2 i t}\right) \times \operatorname{Ln}\left(T A_{i t}\right)$ & $0.0099^{* *}$ & 0.0014 \\
$\operatorname{Ln}\left(w_{2 i t}\right) \times \operatorname{Ln}\left(T A_{i t}\right)$ & $0.1441^{* * *}$ & 0.0075 \\
$\operatorname{Trend}$ & $0.0002^{* * *}$ & 0.0000 \\
$\operatorname{Trend}$ & $0.0000^{* *}$ & 0.0000 \\
$\operatorname{Trend} \times \operatorname{Ln}\left(T A_{i t}\right)$ & $0.0000^{* * *}$ & 0.0000 \\
$\operatorname{Tr} e n d \times \operatorname{Ln}\left(w_{1 i t}\right)$ & $-0.0002^{* * *}$ & 0.0000 \\
$\operatorname{Tr} e n d \times \operatorname{Ln}\left(w_{2 i t}\right)$ & $0.0001^{* * *}$ & 0.0000 \\
$\operatorname{Tr} e n d \times \operatorname{Ln}\left(w_{3 i t}\right)$ & $0.0002^{* * *}$ & 0.0001 \\
\hline $\mathrm{N}$ & \multicolumn{2}{c}{3,350} \\
$R^{2}$ & 0.9965 \\
F-overall test & 0.0000 \\
\hline
\end{tabular}


Table 7: The effects of bank restructuring process on financial stability.

This table provides the regression results of the effects of restructuring process on financial stability. Quarterly observations for Spanish banks are applied from 2002Q1 to 2016Q4 in the whole specifications. The dependent variables are the logarithm of the Z-score $\left(\operatorname{Ln}\left(Z_{i t}\right)\right)$ and the non-performing loans ratio $\left(N P L_{i t}\right)$. $W_{i}$ is a dummy variable which takes the value one if the bank $i$ has been bailed out in period $t$, and zero otherwise. The variable $d_{t}$ is a dummy variable which takes the value one from 2011Q1 onwards, and zero otherwise. The interaction variable $W_{i} \times d_{t}$ represents the effect of the restructuring process. The whole control variables are defined in Table 2. Columns (1) and (3) display the baseline regression, columns (2) and (5) include control variables, and columns (3) and (6) contain interactions of $W_{i}$ with the control variables. Standard errors are in parentheses clustered at the bank level. Estimates followed by $*, * *, * * *$ are statistically significant at the 10 , 5 and $1 \%$ level, respectively.

\begin{tabular}{|c|c|c|c|c|c|c|}
\hline & \multicolumn{3}{|c|}{$\bar{L} \operatorname{Ln}\left(Z_{i t}\right)$} & \multicolumn{3}{|c|}{$\overline{N P L_{i t}}$} \\
\hline & (1) & $(2)$ & $(3)$ & (4) & $(5)$ & (6) \\
\hline \multirow[t]{2}{*}{ Intercept } & $1.482^{* * *}$ & 1.524 & $2.032^{* *}$ & $0.017^{* * *}$ & $0.875^{* * *}$ & $0.924^{* * *}$ \\
\hline & $(0.061)$ & $(0.968)$ & $(0.981)$ & $(0.004)$ & $(0.045)$ & $(0.044)$ \\
\hline \multirow[t]{2}{*}{$W_{i}$} & $-0.170^{* *}$ & $-0.170^{*}$ & -0.081 & $0.005^{*}$ & $0.015^{* * *}$ & $0.019 * * *$ \\
\hline & $(0.075)$ & $(0.099)$ & $(0.138)$ & $(0.001)$ & $(0.005)$ & $(0.005)$ \\
\hline \multirow[t]{2}{*}{$d_{t}$} & $-0.168^{* * *}$ & $-0.053^{*}$ & $-0.072^{* *}$ & $0.042^{* * *}$ & $0.013^{* * *}$ & $0.010^{* * *}$ \\
\hline & $(0.022)$ & $(0.036)$ & $(0.037)$ & $(0.001)$ & $(0.002)$ & $(0.002)$ \\
\hline \multirow{2}{*}{$W_{i} \times d_{t}$} & $-0.083^{*}$ & $-0.072^{*}$ & $-0.195^{* * *}$ & 0.003 & $0.017^{* * *}$ & $0.016^{* * *}$ \\
\hline & $(0.044)$ & $(0.027)$ & $(0.068)$ & $(0.003)$ & $(0.003)$ & $(0.003)$ \\
\hline \multirow{2}{*}{$\operatorname{Ln}\left(H_{t-1}\right)$} & & $0.380 * * *$ & $0.460 * * *$ & & $-0.108^{* * *}$ & $-0.117^{* * *}$ \\
\hline & & $(0.130)$ & $(0.132)$ & & $(0.006)$ & $(0.006)$ \\
\hline \multirow{2}{*}{ Lerner $_{i t-1}$} & & $0.043^{* * *}$ & $0.041^{* * *}$ & & $-0.002 * * *$ & $-0.001^{* * *}$ \\
\hline & & $(0.005)$ & $(0.005)$ & & $(0.000)$ & $(0.000)$ \\
\hline \multirow{2}{*}{$M A_{i t-1}$} & & $0.208 * * *$ & $0.388^{* * *}$ & & $-0.020 * * *$ & $-0.056^{* * *}$ \\
\hline & & $(0.053)$ & $(0.095)$ & & $(0.003)$ & $(0.005)$ \\
\hline \multirow[t]{2}{*}{$I N C_{i t-1}$} & & $0.454^{* * *}$ & $0.225^{* *}$ & & -0.002 & $-0.011^{*}$ \\
\hline & & $(0.106)$ & $(0.115)$ & & $(0.005)$ & $(0.006)$ \\
\hline \multirow[t]{2}{*}{$E F F_{i t-1}$} & & $-0.036^{*}$ & $-0.068^{* * *}$ & & $0.009^{* * *}$ & $0.006^{* * *}$ \\
\hline & & $(0.020)$ & $(0.021)$ & & $(0.001)$ & $(0.001)$ \\
\hline \multirow[t]{2}{*}{$L O A N T A_{i t-1}$} & & $0.270^{*}$ & $0.309^{* *}$ & & $-0.073^{* * *}$ & $-0.052^{* * *}$ \\
\hline & & $(0.145)$ & $(0.146)$ & & $(0.008)$ & $(0.008)$ \\
\hline \multirow{2}{*}{$N P L_{i t-1}$} & & 0.137 & $0.937^{* *}$ & & & \\
\hline & & $(0.393)$ & $(0.426)$ & & & \\
\hline \multirow[t]{2}{*}{$L n\left(H_{t-1}\right) \times W_{i}$} & & & 0.066 & & & $-0.027 * * *$ \\
\hline & & & $(0.073)$ & & & $(0.003)$ \\
\hline \multirow{2}{*}{ Lerner $_{i t-1} \times W_{i}$} & & & $0.030^{*}$ & & & $-0.002^{* * *}$ \\
\hline & & & $(0.018)$ & & & $(0.001)$ \\
\hline \multirow[t]{2}{*}{$M A_{i t-1} \times W_{i}$} & & & $0.313^{* * *}$ & & & $-0.052^{* * *}$ \\
\hline & & & $(0.116)$ & & & $(0.006)$ \\
\hline \multirow[t]{2}{*}{$I N C_{i t-1} \times W_{i}$} & & & $0.917^{* * *}$ & & & $-0.085^{* * *}$ \\
\hline & & & $(0.305)$ & & & $(0.014)$ \\
\hline \multirow[t]{2}{*}{$E F F_{i t-1} \times W_{i}$} & & & $-0.167 * * *$ & & & $0.008^{* * *}$ \\
\hline & & & $(0.051)$ & & & $(0.002)$ \\
\hline \multirow[t]{2}{*}{$L O A N T A_{i t-1} \times W_{i}$} & & & $1.435^{* *}$ & & & $-0.227 * * *$ \\
\hline & & & $(0.620)$ & & & $(0.025)$ \\
\hline \multirow[t]{2}{*}{$N P L_{i t-1} \times W_{i}$} & & & $-5.884^{* * *}$ & & & \\
\hline & & & $(1.202)$ & & & \\
\hline \multirow[t]{2}{*}{ Crisis $_{t}$} & -0.014 & $-0.067^{*}$ & $-0.065^{*}$ & $0.010^{* * *}$ & $0.023^{* * *}$ & $0.024^{* * *}$ \\
\hline & $(0.027)$ & $(0.035)$ & $(0.035)$ & $(0.002)$ & $(0.002)$ & $(0.002)$ \\
\hline Bank fixed effects & YES & YES & YES & YES & YES & YES \\
\hline$N$ & 3,350 & 3,350 & 3,350 & 3,350 & 3,350 & 3,350 \\
\hline$R^{2}$ & 0.139 & 0.101 & 0.132 & 0.422 & 0.581 & 0.617 \\
\hline Wald test & 0.000 & 0.000 & 0.000 & 0.000 & 0.000 & 0.000 \\
\hline
\end{tabular}


Table 8: The effects of bank restructuring process on ROA, CAR and $\sigma(R O A)$.

This table provides the regression results of the effects of restructuring process on the components of the Z-score $\left(Z_{i t}\right)$. Quarterly observations for Spanish banks are applied from 2002Q1 to 2016Q4 in the whole specifications. The dependent variables are return on assets $\left(R O A_{i t}\right)$, the capitalization ratio $\left(C A R_{i t}\right)$ and the three-period rolling window for ROA $\left(\sigma\left(R O A_{i t}\right)\right)$. $W_{i}$ is a dummy variable which takes the value one if the bank $i$ has been bailed out in period $t$, and zero otherwise. The variable $d_{t}$ is a dummy variable which takes the value one from 2011Q1 onwards, and zero otherwise. The interaction variable $W_{i} \times d_{t}$ represents the effect of the restructuring process. The whole control variables are defined in Table 2. Columns (1), (4) and (7) display the baseline regression, columns (2), (5) and (8) include control variables, and columns (3), (6) and (9) contain interactions of $W_{i}$ with the control variables. Standard errors are in parentheses clustered at the bank level. Estimates followed by ${ }^{*}, * *, * * *$ are statistically significant at the 10,5 and $1 \%$ level, respectively.

\begin{tabular}{|c|c|c|c|c|c|c|c|c|c|}
\hline & \multicolumn{3}{|c|}{$\overline{R O A_{i t}}$} & \multicolumn{3}{|c|}{$\overline{C A A R_{i t}}$} & \multicolumn{3}{|c|}{ 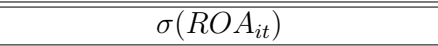 } \\
\hline & $(1)$ & $(2)$ & (3) & (4) & $(5)$ & (6) & (7) & $(8)$ & (9) \\
\hline Intercept & $\begin{array}{c}0.005^{* * *} \\
(0.001)\end{array}$ & $\begin{array}{l}0.036^{*} \\
(0.018)\end{array}$ & $\begin{array}{c}0.024 \\
(0.019)\end{array}$ & $\begin{array}{c}0.072^{* * *} \\
(0.003)\end{array}$ & $\begin{array}{c}0.137^{* * *} \\
(0.028)\end{array}$ & $\begin{array}{c}0.126^{* * *} \\
(0.027)\end{array}$ & $\begin{array}{c}0.027^{* * *} \\
(0.000)\end{array}$ & $\begin{array}{c}0.138^{* * *} \\
(0.014)\end{array}$ & $\begin{array}{c}0.135^{* * *} \\
(0.014)\end{array}$ \\
\hline$W_{i}$ & $\begin{array}{c}-0.003^{* *} \\
(0.002)\end{array}$ & $\begin{array}{l}-0.002 \\
(0.002)\end{array}$ & $\begin{array}{l}-0.001 \\
(0.003)\end{array}$ & $\begin{array}{c}-0.008^{* * *} \\
(0.002)\end{array}$ & $\begin{array}{c}-0.006^{* *} \\
(0.003)\end{array}$ & $\begin{array}{l}-0.002 \\
(0.003)\end{array}$ & $\begin{array}{c}-0.005^{* * *} * \\
(0.001)\end{array}$ & $\begin{array}{l}-0.001^{*} \\
(0.001)\end{array}$ & $\begin{array}{c}-0.005^{* * *} \\
(0.002)\end{array}$ \\
\hline$d_{t}$ & $\begin{array}{c}-0.005^{* * *} \\
(0.000)\end{array}$ & $\begin{array}{c}-0.003^{* * *} \\
(0.001)\end{array}$ & $\begin{array}{c}-0.004^{* * *} \\
(0.001)\end{array}$ & $\begin{array}{c}-0.004^{* * *} \\
(0.001)\end{array}$ & $\begin{array}{c}-0.004^{* * *} \\
(0.001)\end{array}$ & $\begin{array}{c}-0.003^{* * *} \\
(0.001)\end{array}$ & $\begin{array}{c}0.002^{* * *} \\
(0.000)\end{array}$ & $\begin{array}{c}-0.001^{*} \\
(0.001)\end{array}$ & $\begin{array}{l}-0.001 \\
(0.001)\end{array}$ \\
\hline$W_{i} \times d_{t}$ & $\begin{array}{c}-0.003^{* * *} \\
(0.001)\end{array}$ & $\begin{array}{c}-0.006^{* * *} \\
(0.001)\end{array}$ & $\begin{array}{c}-0.010^{* * *} \\
(0.001)\end{array}$ & $\begin{array}{l}-0.000 \\
(0.001)\end{array}$ & $\begin{array}{c}-0.004^{* *} \\
(0.002)\end{array}$ & $\begin{array}{l}-0.003 \\
(0.002)\end{array}$ & $\begin{array}{c}0.005^{* * *} * \\
(0.001)\end{array}$ & $\begin{array}{c}0.001 \\
(0.001)\end{array}$ & $\begin{array}{c}0.000 \\
(0.001)\end{array}$ \\
\hline $\operatorname{Ln}\left(H_{t-1}\right)$ & & $\begin{array}{c}-0.004^{*} \\
(0.002)\end{array}$ & $\begin{array}{l}-0.003 \\
(0.003)\end{array}$ & & $\begin{array}{c}-0.010^{* * *} \\
(0.004)\end{array}$ & $\begin{array}{c}-0.010^{* * *} \\
(0.004)\end{array}$ & & $\begin{array}{c}-0.016^{* * *} \\
(0.002)\end{array}$ & $\begin{array}{c}-0.016^{\text {*** }} \\
(0.002)\end{array}$ \\
\hline Lerner $_{i t-1}$ & & $\begin{array}{c}0.000^{* * *} \\
(0.000)\end{array}$ & $\begin{array}{c}0.000^{* * *} \\
(0.000)\end{array}$ & & $\begin{array}{c}0.000^{* * *} \\
(0.000)\end{array}$ & $\begin{array}{c}0.001^{* * *} \\
(0.000)\end{array}$ & & $\begin{array}{c}-0.000^{* * *} \\
(0.000)\end{array}$ & $\begin{array}{c}-0.000^{* * *} \\
(0.000)\end{array}$ \\
\hline$M A_{i t-1}$ & & $\begin{array}{c}0.002^{* *} \\
(0.001)\end{array}$ & $\begin{array}{c}0.000 \\
(0.002)\end{array}$ & & $\begin{array}{c}0.008 * * * \\
(0.002)\end{array}$ & $\begin{array}{c}0.038^{* * * *} \\
(0.003)\end{array}$ & & $\begin{array}{c}0.001 \\
(0.001)\end{array}$ & $\begin{array}{c}0.000 \\
(0.001)\end{array}$ \\
\hline$I N C_{i t-1}$ & & $\begin{array}{c}0.025^{* * *} \\
(0.002)\end{array}$ & $\begin{array}{c}0.023^{* * *} \\
(0.002)\end{array}$ & & $\begin{array}{c}0.009^{* * *} \\
(0.003)\end{array}$ & $\begin{array}{c}-0.001 \\
(0.003)\end{array}$ & & $\begin{array}{c}-0.004^{* * *} \\
(0.001)\end{array}$ & $\begin{array}{c}-0.005^{* * *} \\
(0.001)\end{array}$ \\
\hline$E F F_{i t-1}$ & & $\begin{array}{c}0.004^{* * *} \\
(0.000)\end{array}$ & $\begin{array}{c}0.004^{* * *} \\
(0.000)\end{array}$ & & $\begin{array}{c}0.001 \\
(0.001)\end{array}$ & $\begin{array}{c}0.000 \\
(0.001)\end{array}$ & & $\begin{array}{l}-0.000 \\
(0.000)\end{array}$ & $\begin{array}{c}0.000 \\
(0.000)\end{array}$ \\
\hline$L O A N T A_{i t-1}$ & & $\begin{array}{c}-0.008^{* * *} \\
(0.003)\end{array}$ & $\begin{array}{c}-0.007^{* * *} \\
(0.003)\end{array}$ & & $\begin{array}{c}0.011^{* *} \\
(0.005)\end{array}$ & $\begin{array}{c}0.030^{* * *} \\
(0.005)\end{array}$ & & $\begin{array}{c}0.001 \\
(0.001)\end{array}$ & $\begin{array}{c}0.001 \\
(0.001)\end{array}$ \\
\hline$N P L_{i t-1}$ & & $\begin{array}{c}-0.071^{* * *} \\
(0.007)\end{array}$ & $\begin{array}{c}-0.054^{* * *} \\
(0.008)\end{array}$ & & $\begin{array}{c}-0.033^{* * *} \\
(0.011)\end{array}$ & $\begin{array}{l}-0.009 \\
(0.012)\end{array}$ & & $\begin{array}{l}-0.006^{*} \\
(0.004)\end{array}$ & $\begin{array}{c}-0.008^{*} \\
(0.005)\end{array}$ \\
\hline $\operatorname{Ln}\left(H_{t-1}\right) \times W_{i}$ & & & $\begin{array}{l}0.002^{*} \\
(0.001)\end{array}$ & & & $\begin{array}{c}0.006^{* * *} \\
(0.002)\end{array}$ & & & $\begin{array}{c}0.001 \\
(0.001)\end{array}$ \\
\hline Lerner $_{i t-1} \times W_{i}$ & & & $\begin{array}{c}0.000 \\
(0.000)\end{array}$ & & & $\begin{array}{c}0.002^{* * *} \\
(0.000)\end{array}$ & & & $\begin{array}{c}0.000 \\
(0.000)\end{array}$ \\
\hline$M A_{i t-1} \times W_{i}$ & & & $\begin{array}{c}0.002 \\
(0.002)\end{array}$ & & & $\begin{array}{c}0.037^{* * *} \\
(0.003)\end{array}$ & & & $\begin{array}{c}0.000 \\
(0.001)\end{array}$ \\
\hline$I N C_{i t-1} \times W_{i}$ & & & $\begin{array}{c}0.001 \\
(0.006)\end{array}$ & & & $\begin{array}{c}0.034^{* * *} \\
(0.008)\end{array}$ & & & $\begin{array}{c}0.003 \\
(0.003)\end{array}$ \\
\hline$E F F_{i t-1} \times W_{i}$ & & & $\begin{array}{c}0.001 \\
(0.001)\end{array}$ & & & $\begin{array}{c}0.003^{* *} \\
(0.001)\end{array}$ & & & $\begin{array}{l}-0.001 \\
(0.001)\end{array}$ \\
\hline$L O A N T A_{i t-1} \times W_{i}$ & & & $\begin{array}{c}-0.022^{* *} \\
(0.010)\end{array}$ & & & $\begin{array}{c}-0.097^{* * *} * \\
(0.016)\end{array}$ & & & $\begin{array}{l}-0.001 \\
(0.005)\end{array}$ \\
\hline$N P L_{i t-1} \times W_{i}$ & & & $\begin{array}{c}-0.095^{* * *} \\
(0.018)\end{array}$ & & & $\begin{array}{l}-0.014 \\
(0.028)\end{array}$ & & & $\begin{array}{c}0.008 \\
(0.008)\end{array}$ \\
\hline Crisis $_{t}$ & $\begin{array}{c}-0.002^{* * *} \\
(0.001)\end{array}$ & $\begin{array}{c}-0.001^{* *} \\
(0.001)\end{array}$ & $\begin{array}{l}-0.001^{*} \\
(0.001)\end{array}$ & $\begin{array}{c}-0.004^{* * *} \\
(0.001)\end{array}$ & $\begin{array}{c}-0.003^{* * *} \\
(0.001)\end{array}$ & $\begin{array}{c}-0.003^{* * *} \\
(0.001)\end{array}$ & $\begin{array}{c}-0.011^{* * *} \\
(0.000)\end{array}$ & $\begin{array}{c}-0.001^{* *} \\
(0.001)\end{array}$ & $\begin{array}{l}-0.001 \\
(0.001)\end{array}$ \\
\hline$N$ & 3113 & 2488 & 2488 & 3350 & 2537 & 2537 & 5040 & 2536 & 2536 \\
\hline Bank fixed effects & YES & YES & YES & YES & YES & YES & YES & YES & YES \\
\hline $\mathrm{N}$ & 3,350 & 3,350 & 3,350 & 3,350 & 3,350 & 3,350 & 3,350 & 3,350 & 3,350 \\
\hline$R^{2}$ & 0.079 & 0.286 & 0.285 & 0.145 & 0.119 & 0.191 & 0.236 & 0.152 & 0.138 \\
\hline Wald test & 0.000 & 0.000 & 0.000 & 0.000 & 0.000 & 0.000 & 0.000 & 0.000 & 0.000 \\
\hline
\end{tabular}


Table 9: The effects of bank restructuring process on liquidity creation and lending supply.

This table provides the regression results of the effects of restructuring process on liquidity creation and lending supply. Quarterly observations for Spanish banks are applied from 2002Q1 to 2016Q4 in the whole specifications. The dependent variables are the liquidity creation to total assets ratio $\left(L C_{i t} / T A_{i t}\right)$ and the loans to total assets ratio $\left(L O A N T A_{i t}\right) . W_{i}$ is a dummy variable which takes the value one if the bank $i$ has been bailed out in period $t$, and zero otherwise. The variable $d_{t}$ is a dummy variable which takes the value one from 2011Q1 onwards, and zero otherwise. The interaction variable $W_{i} \times d_{t}$ represents the effect of the restructuring process. The whole control variables are defined in Table 2. Columns (1), and (4) display the baseline regression, columns (2) and (5) include control variables, and columns (3) and (6) contain interactions of $W_{i}$ with the control variables. Standard errors are in parentheses clustered at the bank level. Estimates followed by *, **, *** are statistically significant at the 10,5 and $1 \%$ level, respectively.

\begin{tabular}{|c|c|c|c|c|c|c|}
\hline & \multicolumn{3}{|c|}{$L L_{i t} / T A_{i t}$} & \multicolumn{3}{|c|}{$L O A N T A_{i t}$} \\
\hline & (1) & $(2)$ & $(3)$ & (4) & $(5)$ & (6) \\
\hline \multirow[t]{2}{*}{ Intercept } & $0.369^{* * *}$ & $0.741^{* * *}$ & $0.572^{* *}$ & $0.651^{* * *}$ & $0.704^{* * *}$ & $0.720^{* * *}$ \\
\hline & $(0.021)$ & $(0.238)$ & $(0.242)$ & $(0.021)$ & $(0.125)$ & $(0.124)$ \\
\hline \multirow[t]{2}{*}{$W_{i}$} & 0.011 & $0.039^{*}$ & 0.030 & $0.019^{* *}$ & 0.007 & 0.006 \\
\hline & $(0.018)$ & $(0.023)$ & $(0.026)$ & $(0.009)$ & $(0.013)$ & $(0.013)$ \\
\hline \multirow[t]{2}{*}{$d_{t}$} & $-0.062^{* * *}$ & $-0.055^{* * *}$ & $-0.056^{* * *}$ & $-0.048^{* * *}$ & $-0.018^{* * *}$ & $-0.011^{* *}$ \\
\hline & $(0.006)$ & $(0.009)$ & $(0.009)$ & $(0.003)$ & $(0.005)$ & $(0.005)$ \\
\hline \multirow[t]{2}{*}{$W_{i} \times d_{t}$} & $-0.028 * *$ & -0.005 & $-0.037^{* *}$ & $-0.021^{* * *}$ & $-0.035^{* * *}$ & $-0.015^{*}$ \\
\hline & $(0.011)$ & $(0.014)$ & $(0.017)$ & $(0.006)$ & $(0.007)$ & $(0.009)$ \\
\hline \multirow[t]{2}{*}{$\operatorname{Ln}\left(H_{t-1}\right)$} & & $0.092^{* * *}$ & $0.064^{*}$ & & $0.189 * * *$ & $0.189^{* * *}$ \\
\hline & & $(0.032)$ & $(0.033)$ & & $(0.016)$ & $(0.016)$ \\
\hline \multirow[t]{2}{*}{ Lerner $_{i t-1}$} & & $0.005^{* * *}$ & $0.005^{* * *}$ & & $-0.003^{* * *}$ & $-0.003^{* * *}$ \\
\hline & & $(0.001)$ & $(0.001)$ & & $(0.001)$ & $(0.001)$ \\
\hline \multirow[t]{2}{*}{$M A_{i t-1}$} & & $0.049^{* * *}$ & $0.089 * * *$ & & $-0.029 * * *$ & $-0.093^{* * *}$ \\
\hline & & $(0.013)$ & $(0.025)$ & & $(0.007)$ & $(0.013)$ \\
\hline \multirow[t]{2}{*}{$I N C_{i t-1}$} & & 0.033 & 0.040 & & $-0.178^{* * *}$ & $-0.165^{* * *}$ \\
\hline & & $(0.027)$ & $(0.029)$ & & $(0.013)$ & $(0.014)$ \\
\hline \multirow{2}{*}{$E F F_{i t-1}$} & & $-0.026^{* * *}$ & $-0.031^{* * *}$ & & $-0.007^{* *}$ & $-0.008 * * *$ \\
\hline & & $(0.005)$ & $(0.006)$ & & $(0.003)$ & $(0.003)$ \\
\hline \multirow{2}{*}{$L O A N T A_{i t-1}$} & & $0.411^{* * *}$ & $0.341^{* * *}$ & & & \\
\hline & & $(0.037)$ & $(0.039)$ & & & \\
\hline \multirow[t]{2}{*}{$\operatorname{Ln}\left(Z_{i t-1}\right)$} & & $0.016^{* * *}$ & $0.024^{* * *}$ & & $0.012^{* * *}$ & $0.013^{* * *}$ \\
\hline & & $(0.005)$ & $(0.006)$ & & $(0.003)$ & $(0.003)$ \\
\hline \multirow[t]{2}{*}{$N P L_{i t-1}$} & & $-0.156^{*}$ & -0.073 & & $-0.595^{* * *}$ & $-0.507^{* * *}$ \\
\hline & & $(0.099)$ & $(0.108)$ & & $(0.051)$ & $(0.055)$ \\
\hline \multirow[t]{2}{*}{$\operatorname{Ln}\left(H_{t-1}\right) \times W_{i}$} & & & $0.070 * * *$ & & & $0.014^{* *}$ \\
\hline & & & $(0.020)$ & & & $(0.007)$ \\
\hline \multirow[t]{2}{*}{ Lerner $_{i t-1} \times W_{i}$} & & & 0.007 & & & -0.003 \\
\hline & & & $(0.005)$ & & & $(0.002)$ \\
\hline \multirow[t]{2}{*}{$M A_{i t-1} \times W_{i}$} & & & 0.047 & & & $-0.070^{* * *}$ \\
\hline & & & $(0.030)$ & & & $(0.015)$ \\
\hline \multirow[t]{2}{*}{$I N C_{i t-1} \times W_{i}$} & & & 0.102 & & & -0.033 \\
\hline & & & $(0.082)$ & & & $(0.037)$ \\
\hline \multirow[t]{2}{*}{$E F F_{i t-1} \times W_{i}$} & & & $-0.028 * *$ & & & -0.007 \\
\hline & & & $(0.013)$ & & & $(0.007)$ \\
\hline \multirow[t]{2}{*}{$L O A N T A_{i t-1} \times W_{i}$} & & & $0.682^{* * *}$ & & & \\
\hline & & & $(0.164)$ & & & \\
\hline \multirow[t]{2}{*}{$L n\left(Z_{i t-1}\right) \times W_{i}$} & & & $0.037^{* * *}$ & & & 0.008 \\
\hline & & & $(0.013)$ & & & $(0.006)$ \\
\hline \multirow[t]{2}{*}{$N P L_{i t-1} \times W_{i}$} & & & -0.020 & & & $-0.938 * * *$ \\
\hline & & & $(0.328)$ & & & $(0.134)$ \\
\hline Crisis $_{t}$ & $-0.032^{* * *}$ & $-0.027^{* * *}$ & $-0.031^{* * *}$ & $-0.025^{* * *}$ & $-0.012^{* * *}$ & $-0.014^{* * *}$ \\
\hline & $(0.007)$ & $(0.009)$ & $(0.009)$ & $(0.004)$ & $(0.004)$ & $(0.004)$ \\
\hline Bank fixed effects & YES & YES & YES & YES & YES & YES \\
\hline $\mathrm{N}$ & 3,350 & 3,350 & 3,350 & 3,350 & 3,350 & 3,350 \\
\hline$R^{2}$ & 0.088 & 0.249 & 0.284 & 0.013 & 0.984 & 0.984 \\
\hline Wald test & 0.000 & 0.000 & 0.000 & 0.000 & 0.000 & 0.000 \\
\hline
\end{tabular}


Table 10: The effects of bank restructuring process on RWA.

This table provides the regression results of the effects of restructuring process on financial stability. Quarterly observations for Spanish banks are applied from 2002Q1 to 2016Q4 in the whole specifications. The dependent variables are the density ratio measured as risk-weighted assets to total assets $\left(R W A_{i t} / T A_{i t}\right)$. $W_{i}$ is a dummy variable which takes the value one if the bank $i$ has been bailed out in period $t$, and zero otherwise. The variable $d_{t}$ is a dummy variable which takes the value one from 2011Q1 onwards, and zero otherwise. The interaction variable $W_{i} \times d_{t}$ represents the effect of the restructuring process. The whole control variables are defined in Table 2. Column displays the baseline regression, column (2) includes control variables, and column (3) contains interactions of $W_{i}$ with the control variables. Standard errors are in parentheses clustered at the bank level. Estimates followed by ${ }^{*}, * *, * *$ are statistically significant at the 10,5 and $1 \%$ level, respectively.

\begin{tabular}{|c|c|c|c|}
\hline & \multicolumn{3}{|c|}{$R W A_{i t} / T A_{i t}$} \\
\hline & (1) & $(2)$ & $(3)$ \\
\hline \multirow[t]{2}{*}{ Intercept } & $0.651^{* * *}$ & 0.169 & 0.140 \\
\hline & $(0.017)$ & $(0.162)$ & $(0.161)$ \\
\hline \multirow{2}{*}{$W_{i}$} & -0.009 & -0.015 & -0.007 \\
\hline & $(0.014)$ & $(0.016)$ & $(0.018)$ \\
\hline \multirow[t]{2}{*}{$d_{t}$} & $-0.086^{* * *}$ & $-0.025^{* * *}$ & $-0.018^{* * *}$ \\
\hline & $(0.005)$ & $(0.006)$ & $(0.006)$ \\
\hline \multirow[t]{2}{*}{$W_{i} \times d_{t}$} & $-0.026^{* * *}$ & $-0.034^{* * *}$ & $-0.006^{*}$ \\
\hline & $(0.008)$ & $(0.009)$ & $(0.001)$ \\
\hline \multirow[t]{2}{*}{$\operatorname{Ln}\left(H_{t-1}\right)$} & & $-0.068^{* * *}$ & -0.017 \\
\hline & & $(0.022)$ & $(0.022)$ \\
\hline \multirow{2}{*}{ Lerner $_{i t-1}$} & & $-0.005^{* * *}$ & $-0.008^{* * *}$ \\
\hline & & $(0.001)$ & $(0.001)$ \\
\hline \multirow{2}{*}{$M A_{i t-1}$} & & -0.001 & -0.002 \\
\hline & & $(0.008)$ & $(0.015)$ \\
\hline \multirow{2}{*}{$I N C_{i t-1}$} & & -0.029 & -0.025 \\
\hline & & $(0.020)$ & $(0.021)$ \\
\hline \multirow{2}{*}{$E F F_{i t-1}$} & & 0.001 & $0.007^{*}$ \\
\hline & & $(0.004)$ & $(0.004)$ \\
\hline \multirow[t]{2}{*}{$L O A N T A_{i t-1}$} & & $0.380^{* * *}$ & $0.451^{* * *}$ \\
\hline & & $(0.026)$ & $(0.027)$ \\
\hline \multirow[t]{2}{*}{$\operatorname{Ln}\left(Z_{i t-1}\right)$} & & $0.028^{* * *}$ & $0.038^{* * *}$ \\
\hline & & $(0.003)$ & $(0.004)$ \\
\hline \multirow[t]{2}{*}{$N P L_{i t-1}$} & & $-0.472^{* * *}$ & $-0.737^{* * *}$ \\
\hline & & $(0.067)$ & $(0.071)$ \\
\hline \multirow[t]{2}{*}{$\operatorname{Ln}\left(H_{t-1}\right) \times W_{i}$} & & & 0.020 \\
\hline & & & $(0.013)$ \\
\hline \multirow[t]{2}{*}{ Lerner $_{i t-1} \times W_{i}$} & & & $-0.012^{* * *}$ \\
\hline & & & $(0.003)$ \\
\hline \multirow[t]{2}{*}{$M A_{i t-1} \times W_{i}$} & & & $-0.040^{* *}$ \\
\hline & & & $(0.018)$ \\
\hline \multirow[t]{2}{*}{$I N C_{i t-1} \times W_{i}$} & & & 0.048 \\
\hline & & & $(0.059)$ \\
\hline \multirow[t]{2}{*}{$E F F_{i t-1} \times W_{i}$} & & & -0.012 \\
\hline & & & $(0.009)$ \\
\hline \multirow[t]{2}{*}{$L O A N T A_{i t-1} \times W_{i}$} & & & -0.118 \\
\hline & & & $(0.108)$ \\
\hline \multirow[t]{2}{*}{$\operatorname{Ln}\left(Z_{i t-1}\right) \times W_{i}$} & & & $0.032^{* * *}$ \\
\hline & & & $(0.008)$ \\
\hline \multirow[t]{2}{*}{$N P L_{i t-1} \times W_{i}$} & & & $-1.373^{* * *}$ \\
\hline & & & $(0.219)$ \\
\hline \multirow[t]{2}{*}{ Crisis $_{t}$} & 0.008 & $0.032^{* * *}$ & $0.029 * * *$ \\
\hline & $(0.006)$ & $(0.006)$ & $(0.006)$ \\
\hline Bank fixed effects & YES & YES & YES \\
\hline $\mathrm{N}$ & 3,350 & 3,350 & 3,350 \\
\hline$R^{2}$ & 0.104 & 0.449 & 0.493 \\
\hline Wald test & 0.000 & 0.000 & 0.000 \\
\hline
\end{tabular}


Table 11: Robustness tests: The Boone's (2008) concentration index and financial stability indicators.

This table provides the regression results of the effects of restructuring process on financial stability. Quarterly observations for Spanish banks are applied from 2002Q1 to 2016Q4 in the whole specifications. The dependent variables are the logarithm of the Z-score $\left(\operatorname{Ln}\left(Z_{i t}\right)\right)$, the non-performing loans ratio $\left(N P L_{i t}\right)$ and the riskweighted assets ratio $\left(R W A_{i t} / T A_{i t}\right) . W_{i}$ is a dummy variable which takes the value one if the bank $i$ has been bailed out, and zero otherwise. The variable $d_{t}$ is a dummy variable which takes the value one from $2011 \mathrm{Q} 1$ onwards, and zero otherwise. The interaction variable $W_{i} \times d_{t}$ represents the effect of the restructuring process. The whole control variables are defined in Table 2. Columns (1), (3) and (5) display the regression including control variables, and columns (2), (4) and (6) contain interactions of $W_{i}$ with the control variables. Standard errors are in parentheses clustered at the bank level. Estimates followed by *, **, *** are statistically significant at the 10,5 and $1 \%$ level, respectively.

\begin{tabular}{|c|c|c|c|c|c|c|}
\hline & \multicolumn{2}{|c|}{$\operatorname{Ln}\left(Z_{i t}\right)$} & \multicolumn{2}{|c|}{$N P L_{i t}$} & \multicolumn{2}{|c|}{$R W A_{i t} / T A_{i t}$} \\
\hline & (1) & $(2)$ & $(3)$ & (4) & (5) & (6) \\
\hline Intercept & $\begin{array}{c}2.661^{* * *} \\
(0.898)\end{array}$ & $\begin{array}{c}2.933^{* * *} \\
(0.902)\end{array}$ & $\begin{array}{c}0.835^{* * *} \\
(0.043)\end{array}$ & $\begin{array}{c}0.875^{* * *} \\
(0.042)\end{array}$ & $\begin{array}{c}0.090 \\
(0.149)\end{array}$ & $\begin{array}{c}0.141 \\
(0.148)\end{array}$ \\
\hline$W_{i}$ & $\begin{array}{c}-0.221^{* *} \\
(0.095)\end{array}$ & $\begin{array}{l}-0.076 \\
(0.137)\end{array}$ & $\begin{array}{c}0.015^{* * *} \\
(0.005)\end{array}$ & $\begin{array}{c}0.020 * * * \\
(0.005)\end{array}$ & $\begin{array}{c}-0.014 \\
(0.016)\end{array}$ & $\begin{array}{l}-0.005 \\
(0.018)\end{array}$ \\
\hline$d_{t}$ & $\begin{array}{c}-0.080^{* *} \\
(0.037)\end{array}$ & $\begin{array}{c}-0.034 \\
(0.037)\end{array}$ & $\begin{array}{c}0.011^{* * *} \\
(0.002)\end{array}$ & $\begin{array}{c}0.009 * * * \\
(0.002)\end{array}$ & $\begin{array}{c}-0.019 * * * \\
(0.006)\end{array}$ & $\begin{array}{c}-0.012^{*} \\
(0.006)\end{array}$ \\
\hline$W_{i} \times d_{t}$ & $\begin{array}{c}-0.024 \\
(0.055)\end{array}$ & $\begin{array}{c}-0.265^{* * *} \\
(0.074)\end{array}$ & $\begin{array}{c}0.014^{* * *} \\
(0.003)\end{array}$ & $\begin{array}{c}0.013^{* * *} \\
(0.004)\end{array}$ & $\begin{array}{c}-0.032^{* * *} \\
(0.009)\end{array}$ & $\begin{array}{l}-0.011 \\
(0.012)\end{array}$ \\
\hline $\operatorname{Ln}\left(H_{t-1}\right)$ & $\begin{array}{c}0.514^{* * *} \\
(0.121)\end{array}$ & $\begin{array}{c}0.561^{* * *} \\
(0.122)\end{array}$ & $\begin{array}{c}-0.101^{* * *} \\
(0.006)\end{array}$ & $\begin{array}{c}-0.110^{* * *} \\
(0.006)\end{array}$ & $\begin{array}{c}-0.060 * * * \\
(0.020)\end{array}$ & $\begin{array}{l}-0.022 \\
(0.020)\end{array}$ \\
\hline$B_{t-1}$ & $\begin{array}{c}0.892^{* * *} \\
(0.253)\end{array}$ & $\begin{array}{c}0.425^{* * *} \\
(0.265)\end{array}$ & $\begin{array}{c}-0.019^{*} \\
(0.009)\end{array}$ & $\begin{array}{c}-0.012^{*} \\
(0.006)\end{array}$ & $\begin{array}{c}-0.010^{* *} \\
(0.004)\end{array}$ & $\begin{array}{c}-0.021^{*} \\
(0.011)\end{array}$ \\
\hline$M A_{i t-1}$ & $\begin{array}{c}0.150^{* * *} \\
(0.052)\end{array}$ & $\begin{array}{c}0.336^{* * *} \\
(0.094)\end{array}$ & $\begin{array}{c}-0.021^{* * *} \\
(0.003)\end{array}$ & $\begin{array}{c}-0.058^{* * *} \\
(0.005)\end{array}$ & $\begin{array}{c}-0.004 \\
(0.008)\end{array}$ & $\begin{array}{l}-0.011 \\
(0.014)\end{array}$ \\
\hline$I N C_{i t-1}$ & $\begin{array}{c}0.514^{* * *} \\
(0.104)\end{array}$ & $\begin{array}{c}0.267^{* *} \\
(0.112)\end{array}$ & $\begin{array}{l}-0.000 \\
(0.005)\end{array}$ & $\begin{array}{c}-0.010^{*} \\
(0.006)\end{array}$ & $\begin{array}{c}-0.017 \\
(0.019)\end{array}$ & $\begin{array}{l}-0.005 \\
(0.020)\end{array}$ \\
\hline$E F F_{i t-1}$ & $\begin{array}{l}-0.023 \\
(0.019)\end{array}$ & $\begin{array}{c}-0.053^{* *} \\
(0.021)\end{array}$ & $\begin{array}{c}0.009^{* * *} \\
(0.001)\end{array}$ & $\begin{array}{c}0.007^{* * *} \\
(0.001)\end{array}$ & $\begin{array}{c}0.002 \\
(0.004)\end{array}$ & $\begin{array}{c}0.002 \\
(0.004)\end{array}$ \\
\hline$L O A N T A_{i t-1}$ & $\begin{array}{c}0.134 \\
(0.140)\end{array}$ & $\begin{array}{c}0.191 \\
(0.144)\end{array}$ & $\begin{array}{c}-0.074^{* * *} \\
(0.007)\end{array}$ & $\begin{array}{c}-0.054^{* * *} \\
(0.008)\end{array}$ & $\begin{array}{c}0.388^{* * *} \\
(0.026)\end{array}$ & $\begin{array}{c}0.456^{* * *} \\
(0.027)\end{array}$ \\
\hline $\operatorname{Ln}\left(Z_{i t-1}\right)$ & & & & & $\begin{array}{c}0.024^{* * *} \\
(0.003)\end{array}$ & $\begin{array}{c}0.030 * * * \\
(0.004)\end{array}$ \\
\hline$N P L_{i t-1}$ & $\begin{array}{c}0.228 \\
(0.377)\end{array}$ & $\begin{array}{c}0.936^{* *} \\
(0.436)\end{array}$ & & & $\begin{array}{c}-0.504^{* * *} \\
(0.063)\end{array}$ & $\begin{array}{c}-0.722^{* * *} \\
(0.067)\end{array}$ \\
\hline $\operatorname{Ln}\left(H_{t-1}\right) \times W_{i}$ & & $\begin{array}{c}0.063 \\
(0.072)\end{array}$ & & $\begin{array}{c}-0.026^{* * *} \\
(0.003)\end{array}$ & & $\begin{array}{c}0.013 \\
(0.013)\end{array}$ \\
\hline$B_{t-1} \times W_{i}$ & & $\begin{array}{c}0.416^{* * *} \\
(0.138)\end{array}$ & & $\begin{array}{c}-0.075^{*} \\
(0.039)\end{array}$ & & $\begin{array}{c}-0.029^{* *} \\
(0.014)\end{array}$ \\
\hline$M A_{i t-1} \times W_{i}$ & & $\begin{array}{c}0.343^{* * *} \\
(0.114)\end{array}$ & & $\begin{array}{c}-0.055^{* * *} \\
(0.006)\end{array}$ & & $\begin{array}{c}-0.028^{* *} \\
(0.013)\end{array}$ \\
\hline$I N C_{i t-1} \times W_{i}$ & & $\begin{array}{c}0.994^{* * *} \\
(0.291)\end{array}$ & & $\begin{array}{c}-0.092^{* * *} \\
(0.014)\end{array}$ & & $\begin{array}{c}0.087 \\
(0.057)\end{array}$ \\
\hline$E F F_{i t-1} \times W_{i}$ & & $\begin{array}{c}-0.157^{* * *} \\
(0.050)\end{array}$ & & $\begin{array}{c}0.009^{* * *} \\
(0.002)\end{array}$ & & $\begin{array}{l}-0.007 \\
(0.009)\end{array}$ \\
\hline$L O A N T A_{i t-1} \times W_{i}$ & & $\begin{array}{c}0.926 \\
(0.612)\end{array}$ & & $\begin{array}{c}-0.206^{* * *} \\
(0.024)\end{array}$ & & $\begin{array}{l}-0.131 \\
(0.109)\end{array}$ \\
\hline $\operatorname{Ln}\left(Z_{i t-1}\right) \times W_{i}$ & & & & & & $\begin{array}{c}0.023^{* * *} \\
(0.008)\end{array}$ \\
\hline$N P L_{i t-1} \times W_{i}$ & & $\begin{array}{c}-3.896^{* * *} \\
(1.219)\end{array}$ & & & & $\begin{array}{c}-1.343^{* * *} \\
(0.220)\end{array}$ \\
\hline Crisis $_{t}$ & $\begin{array}{c}-0.010^{* *} \\
(0.004)\end{array}$ & $\begin{array}{c}-0.008^{* *} \\
(0.003)\end{array}$ & $\begin{array}{c}0.021^{* * *} \\
(0.002)\end{array}$ & $\begin{array}{c}0.022^{* * *} \\
(0.002)\end{array}$ & $\begin{array}{c}0.026^{* * *} \\
(0.006)\end{array}$ & $\begin{array}{c}0.024^{* * *} \\
(0.006)\end{array}$ \\
\hline Bank fixed effects & YES & YES & YES & YES & YES & YES \\
\hline $\mathrm{N}$ & 3,350 & 3,350 & 3,350 & 3,350 & 3,350 & 3,350 \\
\hline$R^{2}$ & 0.183 & 0.147 & 0.293 & 0.383 & 0.444 & 0.499 \\
\hline Wald test & 0.000 & 0.000 & 0.000 & 0.000 & 0.000 & 0.000 \\
\hline
\end{tabular}


Table 12: Robustness tests: The Boone's (2008) concentration index, and liquidity creation and lending supply.

This table provides the regression results of the effects of restructuring process on liquidity creation and lending supply. Quarterly observations for Spanish banks are applied from 2002Q1 to 2016Q4 in the whole specifications. The dependent variables are the liquidity creation to total assets ratio $\left(L C_{i t} / T A_{i t}\right)$ and the loans to total assets ratio $\left(L O A N T A_{i t}\right) . W_{i}$ is a dummy variable which takes the value one if the bank $i$ has been bailed out in period $t$, and zero otherwise. The variable $d_{t}$ is a dummy variable which takes the value one from 2011Q1 onwards, and zero otherwise. The interaction variable $W_{i} \times d_{t}$ represents the effect of the restructuring process. The whole control variables are defined in Table 2. Columns (1) and (3) display the regression including control variables, and columns (2) and (4) contain interactions of $W_{i}$ with the control variables. Standard errors are in parentheses clustered at the bank level. Estimates followed by *, **, *** are statistically significant at the 10 , 5 and $1 \%$ level, respectively.

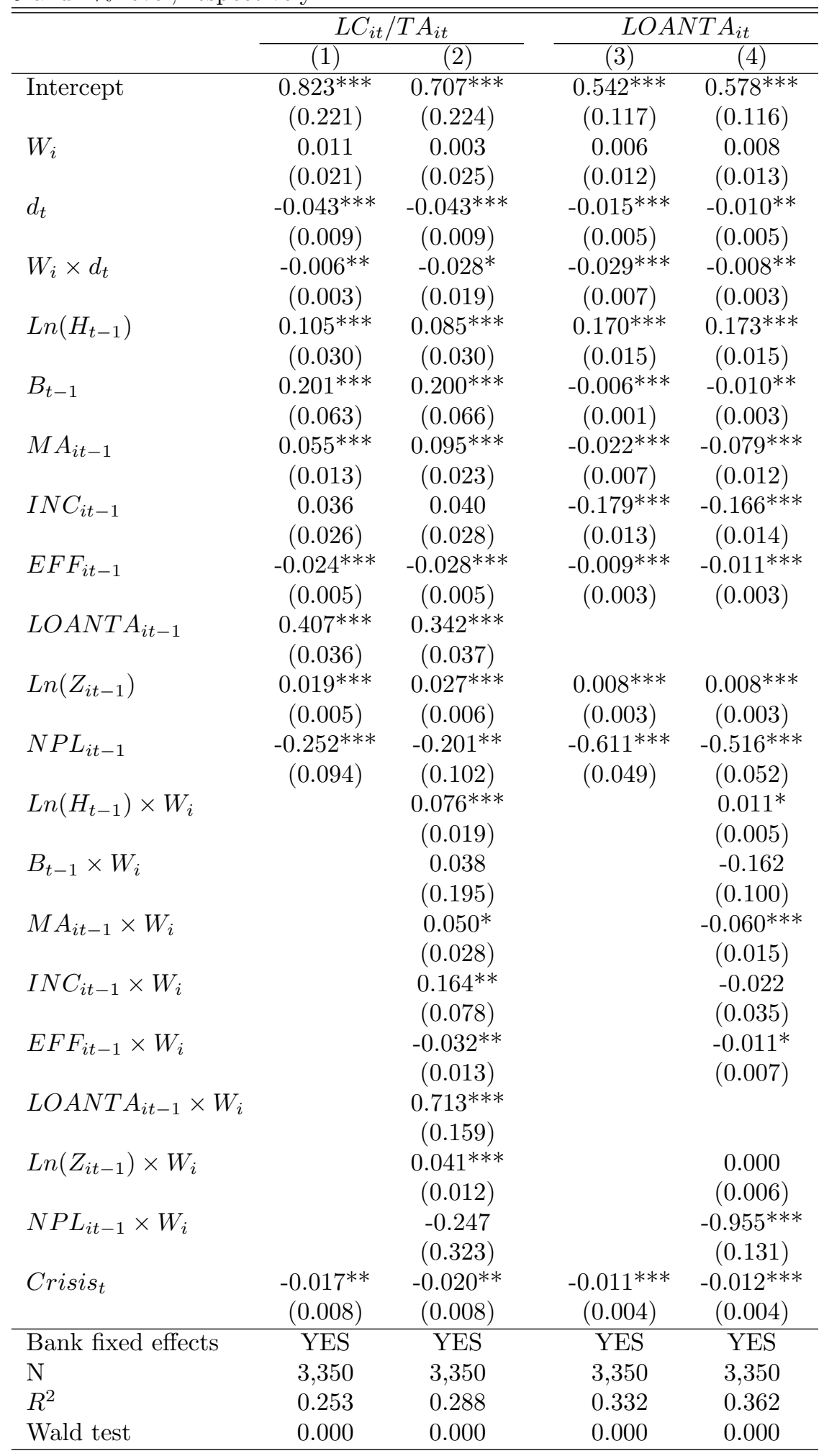




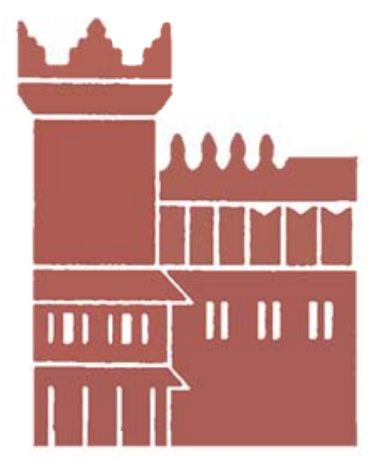

Alma Mater Studiorum - Università di Bologna DEPARTMENT OF ECONOMICS

Strada Maggiore 45

40125 Bologna - Italy

Tel. +39051 2092604

Fax +390512092664

http://www.dse.unibo.it 